\title{
The Impact of Epigenetic Modifications on Adaptive Resistance Evolution in Glioblastoma
}

\author{
Qiong $\mathrm{Wu}^{1}{ }^{1}$, Anders E. Berglund ${ }^{2}\left(\mathbb{D}\right.$ and Arnold B. Etame ${ }^{1, *}$ \\ 1 Department of Neuro-Oncology, H. Lee Moffitt Cancer Center and Research Institute, 12902 Magnolia Drive, \\ Tampa, FL 33612, USA; Qiong.Wu@moffitt.org \\ 2 Department of Biostatistics and Bioinformatics, H. Lee Moffitt Cancer Center and Research Institute, \\ 12902 Magnolia Drive, Tampa, FL 33612, USA; anders.berglund@moffitt.org \\ * Correspondence: Arnold.Etame@moffitt.org
}

Citation: Wu, Q.; Berglund, A.E.; Etame, A.B. The Impact of Epigenetic Modifications on Adaptive Resistance Evolution in Glioblastoma. Int. J. Mol Sci. 2021, 22, 8324. https://doi.org/ $10.3390 /$ ijms 22158324

Academic Editor: Ciro Isidoro

Received: 12 July 2021

Accepted: 30 July 2021

Published: 3 August 2021

Publisher's Note: MDPI stays neutral with regard to jurisdictional claims in published maps and institutional affiliations.

Copyright: (c) 2021 by the authors. Licensee MDPI, Basel, Switzerland. This article is an open access article distributed under the terms and conditions of the Creative Commons Attribution (CC BY) license (https:// creativecommons.org/licenses/by/ $4.0 /)$.

\begin{abstract}
Glioblastoma (GBM) is a highly lethal cancer that is universally refractory to the standard multimodal therapies of surgical resection, radiation, and chemotherapy treatment. Temozolomide (TMZ) is currently the best chemotherapy agent for GBM, but the durability of response is epigenetically dependent and often short-lived secondary to tumor resistance. Therapies that can provide synergy to chemoradiation are desperately needed in GBM. There is accumulating evidence that adaptive resistance evolution in GBM is facilitated through treatment-induced epigenetic modifications. Epigenetic alterations of DNA methylation, histone modifications, and chromatin remodeling have all been implicated as mechanisms that enhance accessibility for transcriptional activation of genes that play critical roles in GBM resistance and lethality. Hence, understanding and targeting epigenetic modifications associated with GBM resistance is of utmost priority. In this review, we summarize the latest updates on the impact of epigenetic modifications on adaptive resistance evolution in GBM to therapy.
\end{abstract}

Keywords: epigenetic modifications; DNA methylation; histone methylation; histone acetylation; chromatin remodeling; glioblastoma; resistance

\section{Introduction}

Glioblastoma (GBM) is a highly lethal tumor that is refractory to the current therapeutic options. The highly invasive and infiltrative nature of GBM precludes complete eradication through surgical resection. Although post-surgical radiation therapy (RT) confers modest increase in overall survival, the addition of temozolomide (TMZ) significantly increases overall survival [1]. However, the multimodal combination GBM therapies of surgical resection, TMZ, and RT provide a median survival of only 15 months in patients with newly diagnosed GBM [1]. The prognosis is markedly dismal in patients with recurrent GBM, whereby a highly resistant phenotype limits the effectiveness of additional chemotherapy [2,3]. The current GBM therapeutic paradigm depends on adjuvant TMZ for durable tumor control that is often short-lived. Hence, acquisition of resistance to TMZ is a critical mechanism of treatment failures in GBM. Identifying and targeting critical mechanisms of resistance in GBM is necessary to impactfully improve survival in GBM.

Therapeutic resistance is a complex process driven by multiple mechanisms that result in survival adaptations in cancer cells [4-6]. Resistance can occur through both genetic and non-genetic mechanisms. For instance, genetic mutations have been shown to play a critical role in mediating therapeutic resistance to a range of standard and targeted chemotherapies in cancers including GBM [7-11]. However, it is also possible for cancer cells to acquire resistance despite the absence of genetic mutations or alterations in drug targets [12-19]. Epigenetic mechanisms, for instance, could contribute to changes in the genome that are independent of DNA alterations in cancer cells. GBM has distinct genetic and epigenetic 
signatures that dictate tumorigenesis [20-24]. Hence, a consideration of the epigenetic complexities of GBM resistance is essential.

Epigenetic mechanisms have been implicated in GBM tumorigenesis and resistance [25-27] (Figure 1). Established epigenetics modifications include DNA methylation, histone methylation/acetylation, chromatin post-translational modification, and non-coding RNAs modification [28,29] (Figure 1). Genes encoding histone methyltransferases, histone demethylases, and histone deacetylases represent critical regulators of epigenetic modifications. Dysregulation of epigenetic regulators can facilitate transcription of genes that promote tumorigenesis [30-33], and resistance [34]. Hence, modulation of the epigenome of cancer cells provides a novel therapeutic approach in overcoming treatment resistance.

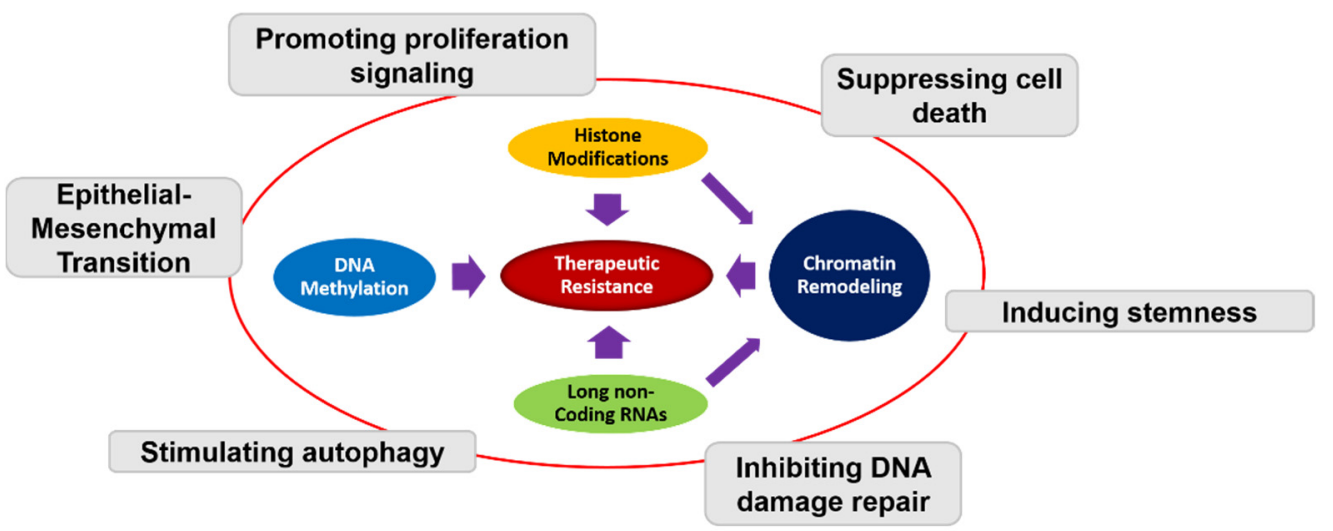

Figure 1. Schematic representation of the interplay between different epigenetic mechanisms and therapeutic resistance in GBM. DNA methylation, histone modifications, chromatin remodeling, and long non-coding RNAs all contribute to therapeutic resistance through different mechanism including promoting proliferation, suppressing cell death, inducing stemness, inhibiting DNA damage repair, stimulating autophagy, and epithelial-mesenchymal transition (EMT).

Therefore, it is essential to understand and target epigenetic events that mediate GBM resistance and recurrence. The epigenetic landscape of GBM has been extensively studied [35-37], and several epigenetic modifications have been identified as potential therapeutic targets in GBM [38,39]. In this review, we will mainly focus on the impact of epigenetic modifications on GBM resistance. We will highlight discoveries on epigenetic modulation of GBM drug resistance. Understanding how epigenetic modifications impact drug resistance in GBM will permit rational targeting of epigenetic modifications in GBM.

\section{Epigenetic Alteration Involved in Drug Resistance of GBM}

Cancer development is a complex process that entails sequential changes in the genome and epigenome. These changes contribute to both tumor heterogeneity, plasticity, and result in alterations in gene expression through modifications of nucleotides and proteins without changes in DNA sequences. Further, cancer cells employ epigenetic mechanisms to regulate gene expression and function in response to stressors [40]. Epigenetic modifications of DNA and histones, together with changes in nucleosome composition and chromatin arrangement therefore serve as an extra layer of gene expression regulation. Epigenetic modifications, such as methylation and acetylation, are catalyzed by specific enzymes and proteins that modify the epigenome rather than genome. The regulatory machinery in epigenetics involves enzymes and proteins that are broadly classified into one of the following categories: the "writers", the "readers", and the "erasers" [41]. The "writers" are enzymes such as DNA methyltransferase, histone lysine methyltransferases, and histone acetyltransferases that are responsible for the addition of modifications such as functional methyl/acetyl groups. The "readers" are proteins or enzymes such as methyl CpG binding proteins and histone methylation/acetylation readers that recognize the presence of epigenetic modifications. The "erasers" are enzymes such as histone demethylases and 
histone deacetylases that erase modifications on DNA/lysine residues and histone proteins. It is now established that epigenetic regulation of modifications impacts upon both nucleosome repositioning and chromatin accessibility resulting in gene expression [41,42]. In the genome, euchromatin regions are loosely packed and easily accessible for transcriptional activation whereas heterochromatin regions are tightly packed and less accessible [42].

Cancer drug resistance accounts for approximately 90\% of cancer-related mortality [43-45]. There is overwhelming evidence that epigenetic modifications represent a potential mechanism for rapid acquisition of drug resistance in cancer [34,46-49]. Similar to other cancers, GBM cells can acquire resistance to drug therapy through multiple mechanisms. In general, both intrinsic genetic resistance and treatment-induced resistance are common mechanisms through which GBM cells can attain survival adaptation (Figure 2). GBM cells with drug target genetic mutations that confer resistance to therapy will persist. In addition, a small population of tumor cells without prior genomic mutations can transcriptionally evolve into drug tolerant status and persist despite treatment (Figure 2). This plasticity towards adaptive resistance is largely influenced by epigenetic modifications [44,46]. In GBM, phenotypic plasticity to radiation therapy has been observed from the residual glioma stem cell populations that exist beyond the confines of resected tumor [50]. Since such residual glioma stem cells exist beyond the extent of surgically resected disease, they serve a nidus for recurrence and lethality in GBM.

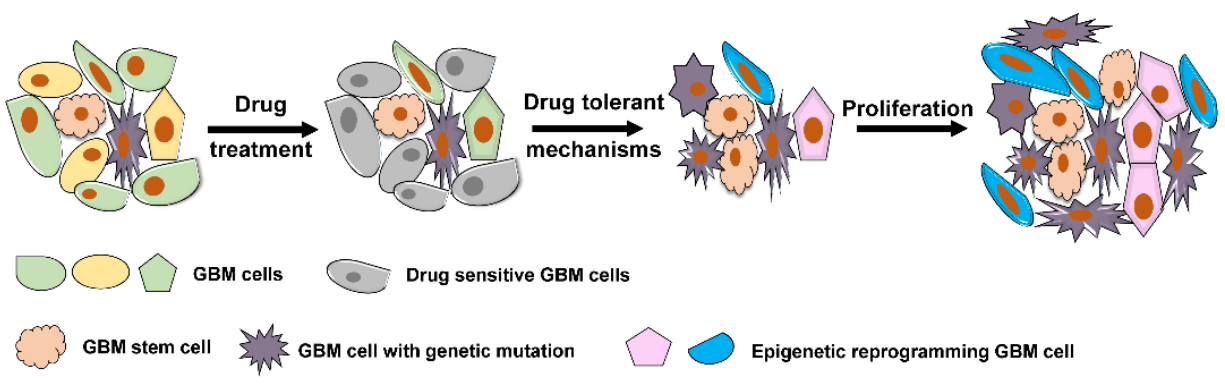

Figure 2. Representative mechanism underlying drug resistance in GBM. GBM cells that carry resistance-conferring mutation(s) in a heterogeneous cancer population and GBM stem cells that are intrinsically resistant to drug treatment survive drug exposure and outgrow to determine the further cancer population. A group of GBM cells evolved through epigenetic reprogramming become drug-tolerant cells and further confer resistance to drug therapy.

\section{Targeting Epigenetic Alteration}

DNA methylation, histone modifications, chromatin remodeling, and long non-coding RNAs (lncRNAs) are the main mechanisms of epigenetic regulation of transcriptional activation in cancers such as GBM. Since epigenetic modifications drive tumorigenesis and therapeutic resistance, there is a potential clinical benefit in targeting epigenetic regulators in GBM patients (Figure 3). Several epigenetic agents including histone methyltransferase inhibitors, DNA methyltransferase inhibitors, histone deacetylase inhibitors, and other agents are currently being tested in GBM patients in clinical trials (Table 1). 


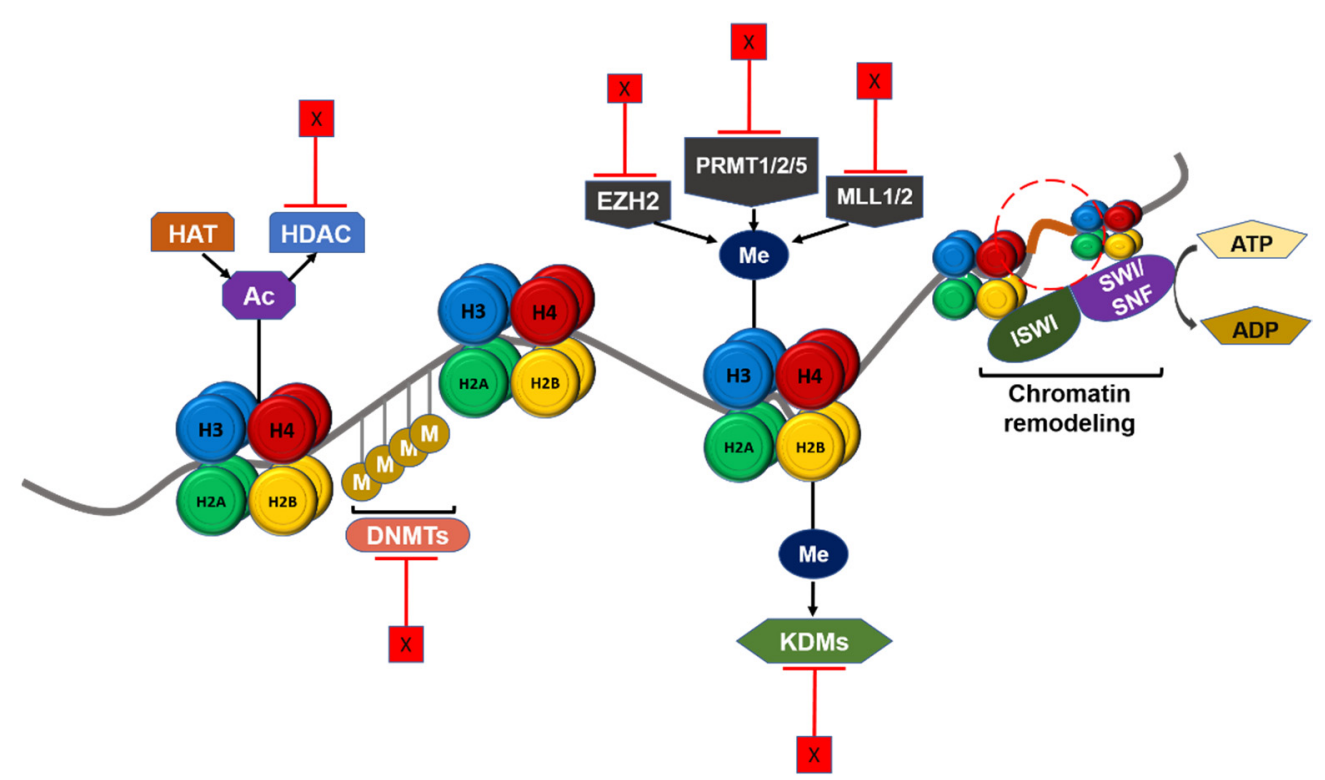

Figure 3. Schematic summary of epigenetic regulation in GBM and potential therapeutic targets. Chromatin structure and gene transcription are regulated by epigenetic mechanisms. DNA methyltransferase (DNMT), histone lysine acetyltransferase (HAT), and histone lysine methyltransferase (KMT) such as EZH2, PRMTs, and MLL1/2 catalyze the addition of epigenetic groups to either DNA or histone tails. Histone deacetylase (HDAC) and histone demethylase (KDM) remove these epigenetic groups. ISWI and SWI/SNF complex could remodel chromatin structure according to histone modifications. These regulators can be targeted in therapeutic treatment against GBM, and furthermore the targets shown here are either under pre-clinical studies or approved and under clinical trials. Ac: Acetyl group. M/Me: Methyl group. X: Inhibition. 
Table 1. Development of combination therapy using epigenetic drugs for the treatment of GBM.

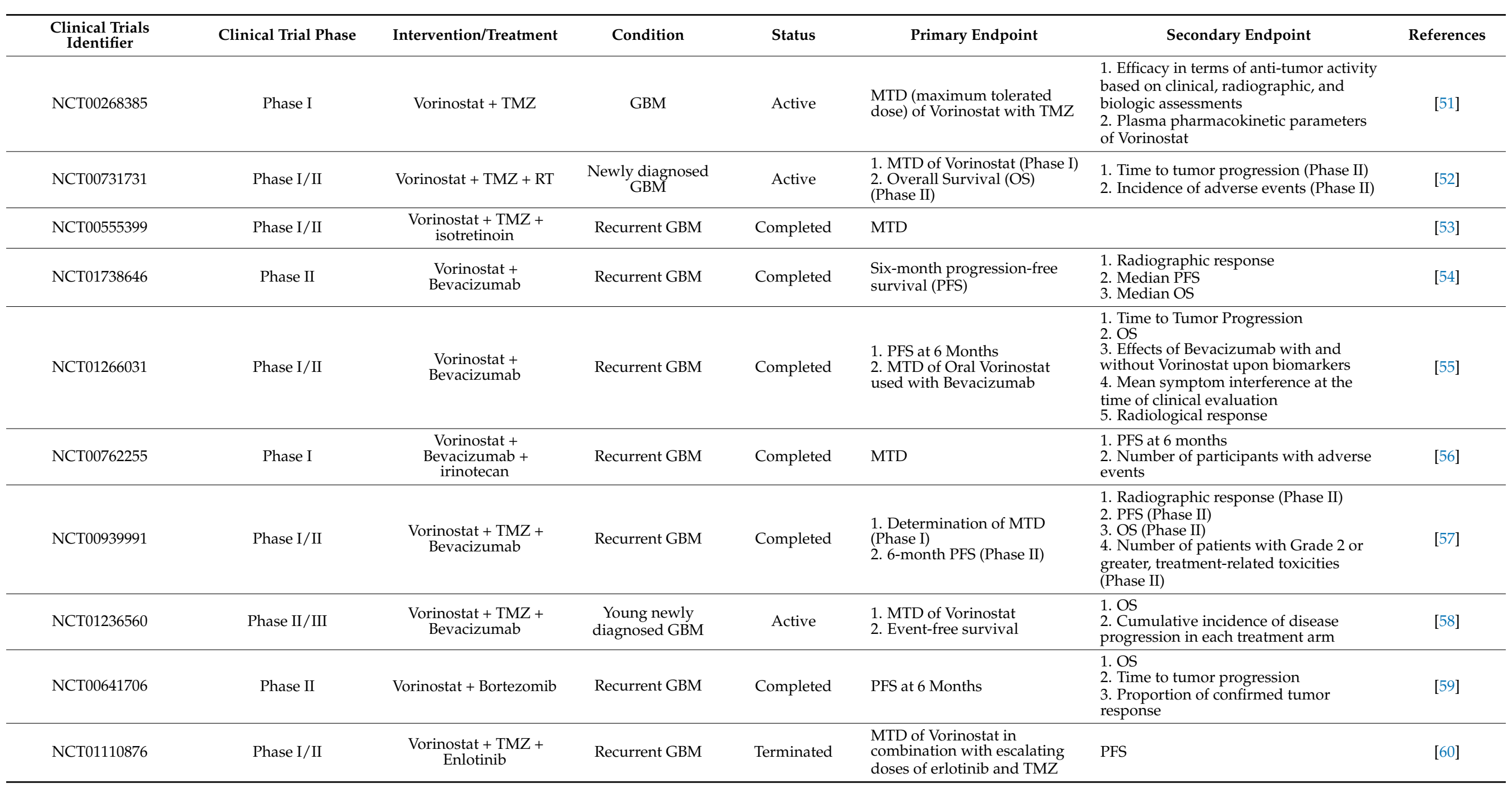


Table 1. Cont.

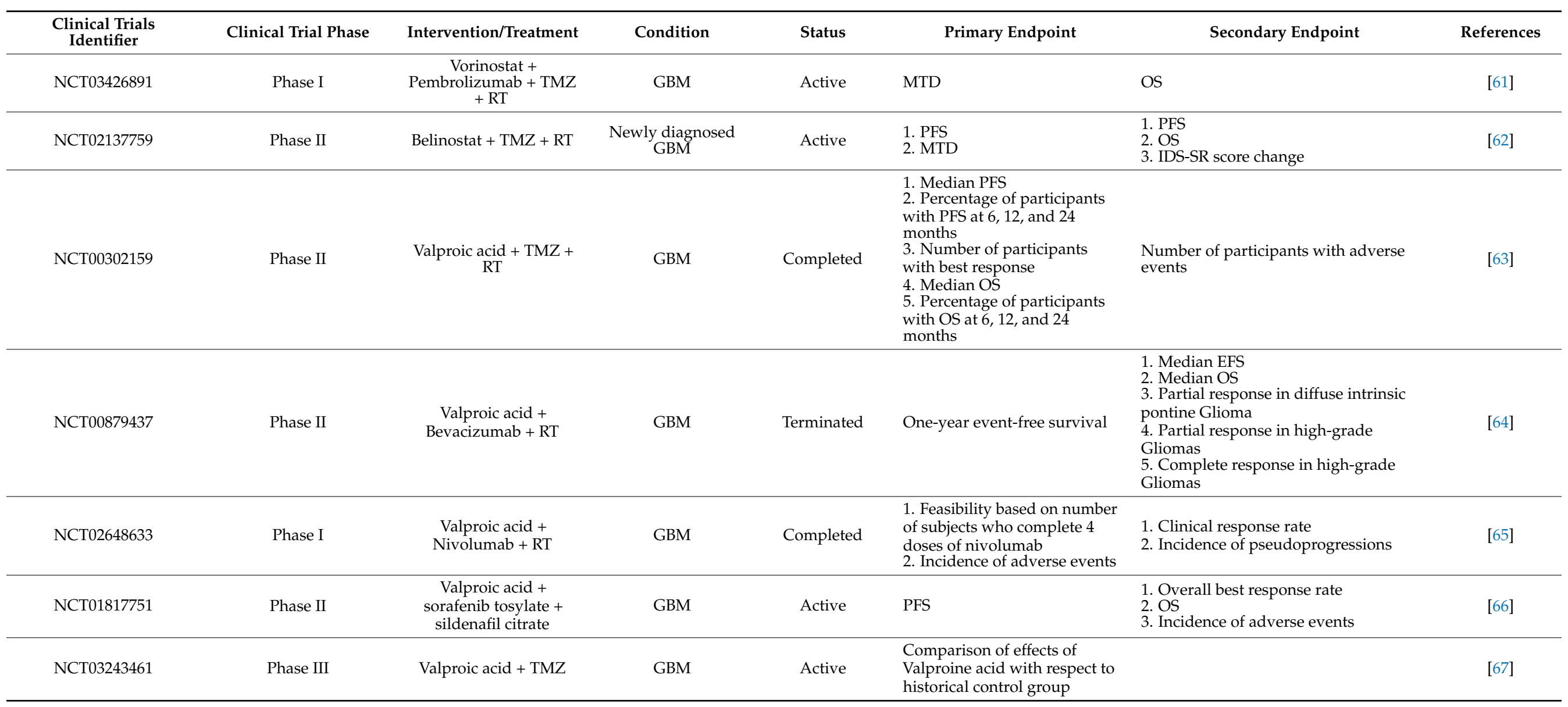


Table 1. Cont.

\begin{tabular}{|c|c|c|c|c|c|c|c|}
\hline $\begin{array}{l}\text { Clinical Trials } \\
\text { Identifier }\end{array}$ & Clinical Trial Phase & Intervention/Treatment & Condition & Status & Primary Endpoint & Secondary Endpoint & References \\
\hline NCT00859222 & Phase I/II & $\begin{array}{c}\text { Bevacizumab }+ \\
\text { Panobinostat }\end{array}$ & Recurrent GBM & Completed & $\begin{array}{l}\text { 1. LBH589 MTD (Phase I) } \\
\text { 2. Dose limiting toxicity } \\
\text { (Phase I) } \\
\text { 3. PFS at } 6 \text { months (Phase II) }\end{array}$ & $\begin{array}{l}\text { 1. Best radiographic response } \\
\text { 2. PFS (Phase II) } \\
\text { 3. OS (Phase II) }\end{array}$ & [68] \\
\hline NCT03684811 & Phase I/II & Azacitidine + FT-2102 & GBM & Active & $\begin{array}{l}\text { 1. Number of participants } \\
\text { with dose limiting toxicity } \\
\text { (Phase 1) } \\
\text { 2. Doses recommended for } \\
\text { future studies (Phase 1) } \\
\text { 3. Objective response rate of } \\
\text { FT-2102 single agent or in } \\
\text { combination with Azacitidine } \\
\text { (Phase 2) }\end{array}$ & $\begin{array}{l}\text { Phase } 1 \text { and } 2 \text { : } \\
\text { 1. OS } \\
\text { 2. Time to response (TTR) } \\
\text { 3. Time to tumor progression } \\
\text { 4. Duration of response (DOR) } \\
\text { 5. PFS } \\
\text { 6. Drug level within CSF }\end{array}$ & [69] \\
\hline NCT04614909 & Early Phase I & Olaparib + TMZ + RT & $\begin{array}{l}\text { Newly diagnosed } \\
\text { GBM }\end{array}$ & Active & $\begin{array}{l}\text { Systemic plasma PK profile } \\
\text { parameters }\end{array}$ & $\begin{array}{l}\text { 1. PFS participants with demonstrated } \\
\text { PK effects } \\
\text { 2. OS } \\
\text { 3. Drug-related toxicity } \\
\text { 4. Adverse events } \\
\text { 5. Treatment-emergent adverse events } \\
\text { 6. Deaths }\end{array}$ & [70] \\
\hline NCT02152982 & Phase II/III & Veliparib + TMZ & $\begin{array}{l}\text { Newly diagnosed } \\
\text { GBM }\end{array}$ & Active & OS & $\begin{array}{l}\text { 1. Interaction with Optune device } \\
\text { 2. PFS } \\
\text { 3. Objective tumor response } \\
\text { 4. Overall adverse event rates for grade } 3 \\
\text { or higher adverse events } \\
\text { 5. Change in quality of life (QOL) }\end{array}$ & [71] \\
\hline NCT01026493 & Phase I/II & Veliparib + TMZ & Recurrent GBM & Completed & $\begin{array}{l}\text { 1. MTD (Phase I) } \\
\text { 2. 6-month PFS rate for } \\
\text { patients with measurable } \\
\text { disease after surgery (Phase II) }\end{array}$ & $\begin{array}{l}\text { Phase II: } \\
\text { 1. Objective response rate for patients } \\
\text { with measurable disease after surgery } \\
\text { 2. OS }\end{array}$ & [72] \\
\hline NCT03581292 & Phase II & Veliparib + TMZ + RT & GBM & Active & Event-free Survival & $\begin{array}{l}\text { 1. Objective response } \\
\text { 2. OS }\end{array}$ & [73] \\
\hline
\end{tabular}




\subsection{DNA Methylation}

DNA methylation is one of the best characterized epigenetic modifications whereby DNA methyltransferases (DMNTs) preferentially methylate the C-5, N-4, N-6, and N-7 sites of DNA $[74,75]$. GBM methylation alterations can manifest as genome-wide hypomethylation, gene-specific hypomethylation, or hypermethylation [76-80]. DMNTs catalyze the transfer of methyl group S-adenosylmethionine to the fifth carbon of cytosine residue and form 5-metylcytosine as part of the DNA methylation process. In GBM, intrinsic DNA methylation has a significant impact on response to TMZ, the standard of care chemotherapy. TMZ is an alkylating agent responsible for methylation of guanine in position N7 and O6, and Adenine in N3. The role of DNMTs with respect to TMZ sensitivity in GBM has not been fully explored. Zhou et al. investigated whether DNMTs expression was associated with TMZ sensitivity in GBM cells and elucidated the underlying mechanism [81]. DNA methyltransferase 1 (DNMT1) expression was found to be downregulated in TMZ resistant GBM cells, negatively correlated with miR-20a expression, and positively correlated with TMZ sensitivity [81]. However, these findings were reported using a single GBM cell line that might not fully recapitulate the cellular hierarchical heterogeneity GBM stem cells.

O-6-methylguanine-DNA methyltransferase (MGMT) is a critical DNA damage repair gene, responsible for repairing DNA lesions of O6 adducts created by alkylating chemotherapy agent such as TMZ. MGMT expression is highly regulated through promoter methylation whereby hypermethylation of the MGMT promoter results in epigenetic silencing of MGMT expression leading to enhanced clinical response to TMZ [82,83]. Similarly, GBM patients with unmethylated MGMT promoter status demonstrated a worse response to TMZ [84]. Hence MGMT promoter methylation serves as a prognostic surrogate for TMZ response in GBM [84]. However, strategies to target MGMT have failed to improve TMZ response and survival in GBM patients in clinical trials [85,86]. Accordingly, there are likely other epigenetic mechanisms besides MGMT promoter methylation that impact upon adaptive resistance to TMZ. For instance, epigenetic regulation of XIAP associated factor 1 (XAF1), a previously reported tumor suppressor was recently reported to mediate plasticity towards adaptive resistance in GBM to TMZ [87].

Moreover, chemotherapy agents such as TMZ can induce DNA methylation alterations throughout the entire genome through mechanisms that are not completely understood [88-90]. It is also not clear why drug-induced hypermethylation selectively leads to a resistant phenotype as opposed to a sensitive phenotype in cancer cells. Methylation alterations involving promoters that modulate drug efflux transporters, pro-apoptotic genes, and DNA damage repair genes are potential contributory mechanisms towards drug resistance [82,91-93]. Other potential mechanisms of resistance include methylation alterations at enhancer sites on the genome. Collective evidence from recurrent GBM tumor tissues and TMZ resistant patient-derived xenografts implicates activation of an enhancer region between marker of proliferation Ki67 and MGMT promoters as a driver of TMZ resistance [94]. TMZ sensitivity was restored following deletion of this enhancer region even in GBM cells with high MGMT expressions [94].

Given the established link between DNA hypermethylation and drug resistance, it has been suggested that DNA demethylation provides a novel therapeutic avenue to enhance TMZ sensitivity. Hence, there have efforts to evaluate demethylating agents as anti-cancer drugs. It should be noted that demethylating agents can have widespread unwanted systemic effects given the lack of selectivity. Such agents have been used to reverse DNA hypermethylation related resistance in GBM [95-97]. There is further preclinical and clinical evidence that demethylating agents are more effective when used in combination with other cancer therapies [69].

\subsection{Histone Modification}

The role of histone modifications on gene regulation in GBM is well recognized. Histone modifications alter gene expression without changing the DNA sequences and are catalyzed by specific enzymes and related proteins at four core histone proteins: H2A, $\mathrm{H} 2 \mathrm{~B}, \mathrm{H} 3$, and H4. The most common modifications include acetylation, methylation, 
phosphorylation, and ubiquitylation. Histone acetylation results in gene activation while histone methylation can result to either gene activation or gene repression depending on the histone protein core and amino acid residue [98]. Abnormalities in histone modification can facilitate transcription of genes that drive GBM propagation, contributing to therapeutic resistance [99-101]. For instance, enhancer of zeste homolog 2 (EZH2) is a histone methyltransferase in the polycomb repressive complex 2 (PRC2) that has been implicated in cancer propagation [102]. EZH2 expression is high in GBM and negatively impacts GBM survival [103]. EZH2 mechanistically upregulates c-MYC expression [104] and increases signal transducer and activator of transcription 3 (STAT3) phosphorylation [105], leading to GBM tumorigenesis and making EZH2 a compelling epigenetic target.

Methylation of arginine residues is one of the most common post-translational modifications of histone proteins. Methylation of arginine residues disrupts protein-protein interactions and associated downstream cellular processes. Protein arginine methyltransferases (PRMTs) are critical enzymes responsible for adding methyl groups onto arginine residues within target proteins. Emerging evidence within the last decade suggests a strong nexus between aberrancies in PRMTs function and GBM tumorigenesis [106,107]. Hence, PRMT inhibitors are currently under development for preclinical and clinical trials in GBM patients. Protein arginine methyltransferase 5 (PRMT5) [108-110], and protein arginine methyltransferase 1 (PRMT1) [111] are members of the PRMT family proteins which are over-expressed in GBM and have a negatively impact upon patient survival. Genetic depletion of either PRMT5 [110,112,113] or PRMT1 [111] significantly inhibits tumor growth in intracranial orthotopic mouse xenograft models. Furthermore, small molecule inhibitors of PRMT5 can drive GBM stem-like cells into senescence [113]. Recently, it was identified that protein arginine methyltransferase 6 (PRMT6) is required for methylation of regulator of chromatin condensation 1 (RCC1) and further induce proliferation, stem-like properties and tumorigenicity of GBM stem cells (GSCs) [114]. Depletion of PRMT6 with a small molecule inhibitor could suppress $R C C 1$ arginine methylation and improve the cytotoxic activity of radiotherapy against GSCs in vitro and in vivo.

The lysine demethylase (KDM) genes are histone modification enzymes that also have a very important role in GBM resistance. KDM genes have been implicated in the dysregulation of senescence, apoptosis, and tumor progression $[115,116]$. Particularly, lysine demethylase 2B (KDM2B) [117] and lysine demethylase 1A (KDM1A) [118,119] propagate survival adaptation towards a stemness phenotype in GBM [117]. Depletion of either KDM2B [117] or pharmacological inhibition of KDM1A [118,119] could induce apoptosis in GBM. Lysine demethylase 5A (KDM5A), an H3K4 demethylase, was found to be overexpressed in GBM cells that were adaptively resistant to TMZ [120,121]. Importantly, inactivation of KDM5A can efficiently restore TMZ sensitivity in adaptively resistant GBM cells [120,121]. Inhibition of KDM5A with small molecule inhibitors such as the pan-KDM inhibitor JIB 04 and the selective KDM5A inhibitor CP1445 efficiently inhibited tumor growth in vitro and in vivo of TMZ-resistant GBM [120,121]. KDM6B is a histone H3K27 demethylase that was investigated as a potential target for GBM treatment recently [121,122]. Lysine demethylase 6B (KDM6B) was overexpressed in GBM tissues and treatment with KDM5B specific inhibitor GSK-J4 significantly improved survival in GBM models of diffuse intrinsic pontine gliomas. Furthermore, the combination of KDM5A inhibitor JIB 04 and KDM6B inhibitor GSK-J4 resulted in significant synergy and potency against TMZ resistant GBM cells [121].

The inter-dynamics between histone acetylation and deacetylation in maintaining a balanced state of acetylation is critical to the regulation of gene transcription. Acetylation and deacetylation are mediated by histone acetyltransferases (HAT) and histone deacetylases (HDAC), respectively. Acetylation occurs through addition of acetyl groups to $\mathrm{H} 3$ and $\mathrm{H} 4$ and weakens the interaction between the histone core and DNA leading to facilitated transcription. HDACs are overexpressed and mutated in various solid and hematologic malignancies and play key roles in tumorigenesis $[123,124]$. HDACs have been implicated in chemoradiation resistance through inhibition of DNA double-strand break repair $[125,126]$. Furthermore, HDAC-mediated resistance to TMZ is easily reversed 
with inhibitors of HDACs in GBM [127-131]. HDAC inhibitors target several processes that are integral to tumorigenesis including the induction of cell cycle arrest, differentiation, senescence, cell death, and inhibition of angiogenesis [132,133]. Several HDAC inhibitors have already been approved by the FDA including Vorinostat, Belinostat, Romidepsin, Belinostat, Valproic acid, and Panobinostat. Given the role of HDACs in GBM, HDAC inhibitors have been extensively studied in GBM clinical trials (Table 1). The results so far suggest that HDAC inhibitors such as Vorinostat have no impact on overall survival even when combined with chemotherapy [134]. Moreover, besides issues with efficacy, HDAC inhibitors have undesirable side effect profiles which remain a huge impediment [135-137] (Table 1). A possible avenue for consideration is the combination of HDACs and KDM inhibitors based on reports that pharmacological inhibition of KDM1A can sensitize GBM cells to HDAC inhibitors in-vivo [138]. Further studies are necessary to determine the optimal combinatorial strategies for HDACs that permit efficacy as well as safety in GBM. Targeting HDAC-mediated resistance in GBM remains an active area of investigation.

\subsection{Chromatin Remodeling}

In addition to histone and genomic alterations, the impact of chromatin remodeling also plays a critical role in drug resistance. Remodeling entails the assembly of chromatin complexes into a high-order chromatin structure. These high-order chromatin structures can impact upon drug resistance, depending on whether the resulting accessibility permits transcription of drug-resistant signaling pathways. For instance, poly (ADP-ribose) polymerase 1 (PARP1), a critical enzyme involved in chromatin remodeling mechanisms, has emerged as an attractive target, and there are currently two FDA-approved PARP inhibitors, Oliparib and Veliparib [139].

Many studies have examined the role of chromatin remodeling on adaptive resistance evolution in GBM. In response to targeted kinase inhibitors, a small subset GBM stem cells will transition towards a survival adaptive state that is associated with the upregulation of histone demethylases KDM6A/B and widespread chromatin remodeling from disruptions of H3K27 trimethylated genomic regions [16]. Additional support for chromatin remodeling in GBM resistance to tyrosine-kinase pathway inhibitors has emerged from examining components of the tumor suppressor SWItch/Sucrose Non-Fermentable (SWI/SNF) complex which is critical for chromatin remodeling [140]. The Brahma-related gene 1 (BRG1) subunit of the SWI/SNF complex was implicated in GBM stemness and genetic/pharmacological of BRG1 reversed GBM stemness and enhanced sensitivity to alkylating chemotherapy [140]. Similar observations were noted by Hiramatsu and colleagues that SWI/SNF core complex plays essential roles in stemness maintenance in GSCs through association with a corepressor complex involving the d4-family proteins, DPF1/DPF3a [141].

Further evidence that chromatin remodeling is a critical mechanism of TMZ drug resistance in GBM has emerged from evaluating recurrent GBM tumors. Bruns et al. recently showed that chromatin remodeling influenced the transcription programs in paired recurrent versus newly diagnosed GBM patient tissues [142]. Specifically, treatmentinduced alterations in GBM sensitivity are mediated through differential transcriptional hierarchies influenced by the chromatin remodeling machinery [142].

Chromatin remodeling is undoubtedly an integral part of therapeutic resistance evolution in GBM. Given the complexities of high-order chromatin structures, it is not surprising that targeting chromatin remodeling has been a challenge. Nevertheless, PARP inhibitors are currently in trial for GBM $[70-73,143]$. It is anticipated that anti-chromatin remodeling agents such as PARP inhibitors will overcome GBM resistance through preventing dynamic chromatin rearrangements.

\subsection{Long Non-Coding RNAs}

Long non-coding RNAs (lncRNAs) represent RNA molecules with a length of more than 200 nucleotides, which do not encode proteins [144]. These RNA molecules demon- 
strate widespread expression and impact on gene expression through interactions with the cellular epigenetic machinery. LncRNAs can therefore affect chromatin remodeling and other chromatin-associated functions. Structurally, lncRNAs retain 5-cap and alternative splicing features, but lack functional open reading frames (ORFs) required to encode proteins [145]. LncRNAs are dysregulated in multiple cancer types, including GBM $[146,147]$. By interacting with the epigenetic machinery in cancer cells, lncRNAs contribute to malignant neoplastic phenotypes such as metastasis, proliferation, and therapeutic resistance [148] (Figure 4).

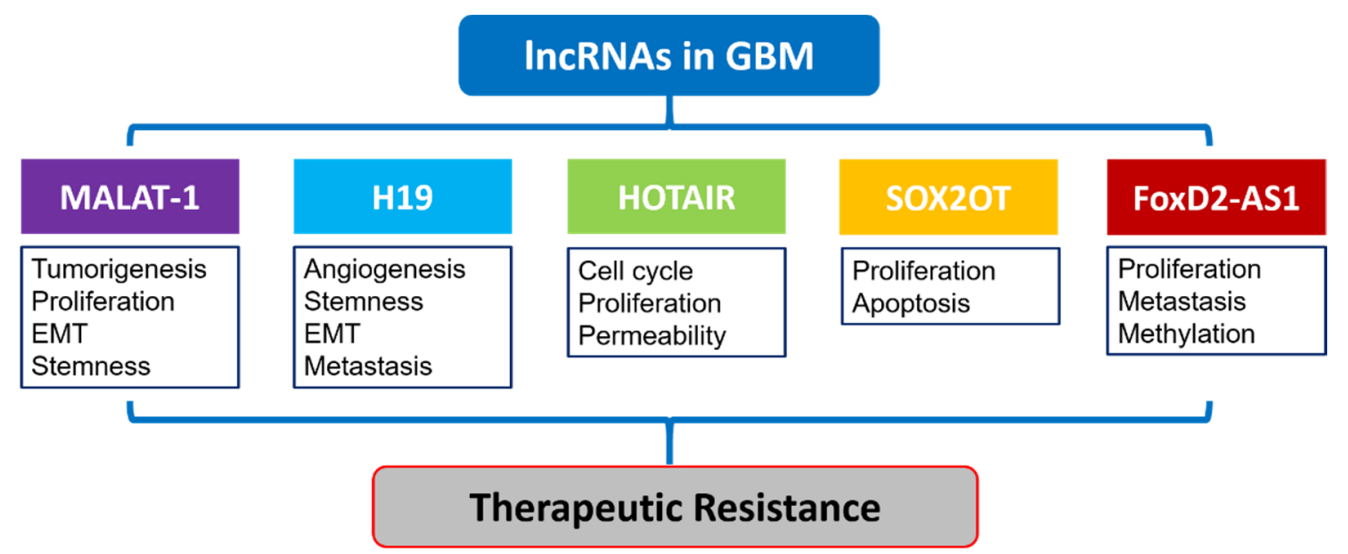

Figure 4. Schematic summary of several important lncRNAs in therapeutic resistance of GBM. The IncRNAs MALAT-1. H19, HOTAIR, SOXOT, and FoxD2-AS1 are involved in the therapeutic resistance of GBM through different mechanisms including tumorigenesis, proliferation, EMT, angiogenesis, stemness, metastasis, cell cycle, and apoptosis.

The role of lncRNAs in GBM therapeutic resistance has recently emerged as an area of great interest and active investigation. Advances in bioinformatic approaches have permitted large scale analysis of differential expression of lncRNAs in treatment-naïve versus treatment resistant GBMs as well as comparisons between GBM and normal brain. In a recent study, approximately 300 lncRNAs were reported to be differentially expressed in TMZ resistant GBM patient tissues [149]. Furthermore, TMZ resistant GBMs had a propensity for dysregulation of lncRNAs, lending support for a potential role of lncRNAs in GBM drug resistance [149]. Besides their role in therapeutic resistance, lncRNAs have also been implicated in oncogenic signaling in GBM. Several studies have provided a nexus between oncogenic signaling and treatment resistance in GBM [150-154].

Metastasis-associated lung adenocarcinoma transcript 1 (MALAT1) is an oncogenic lncRNA that is highly expressed in GBM and that drives tumorigenesis and tumor propagation through regulations of miR-129, SOX2, and non-canonical Wnt signaling [152,154]. Furthermore, dysregulation of MALAT1 has been implicated as a contributor towards TMZ resistance of GBM in several studies [150,151,153,155,156]. Voce and colleagues examined how activation of MALAT1 during TMZ treatment of GBM cell lines contributed to TMZ resistance [153]. The investigators demonstrated that MALAT1 expression was induced through nuclear factor kappa-light-chain-enhancer of activated B cells (NF- $\mathrm{kB}$ ) and p53 signaling [153]. They further showed that MALAT1 depletion restored TMZ sensitivity in patient-derived GBM cells both in vitro and in vivo [153]. In another study where MALAT1 was reported to be upregulated in GBM during TMZ resistance, depletion of MALAT1 restored TMZ sensitivity through mechanistic upregulation of miR-101 and downregulation of GSK-3 $\beta$ in resistant GBM cells [150]. Besides TMZ sensitivity, genetic silencing of MALAT1 significantly attenuated oncogenic phenotypes of cell growth, motility, and stemness in GBM $[151,156]$. Others have postulated that treatment-induced upregulation of MALAT1 promotes GBM chemoresistance and oncogenic proliferation through suppression of miR-203 [155]. The above studies implicate MALAT1 as a facilitator of chemo-resistance in GBM and therefore a potential target for chemosensitization. These encouraging find- 
ings pave the way for future directions in developing novel strategies to overcome TMZ resistance in GBM.

H19 is another oncogenic lncRNA, whose upregulation was associated with GBM cell invasion, angiogenesis, and neurosphere formation [157]. Jiang and colleagues established the correlation between H19 expression and TMZ drug resistance in GBM, by demonstrating that $\mathrm{H} 19$ silencing decreased the IC-50 against TMZ and significantly increased apoptosis in GBM cells [158]. Duan and colleagues confirmed the above observations and demonstrated that H19 was upregulated through oxidative stress, and H19 expression contributed to TMZ resistance through NF-KB signaling activation [159]. Moreover, in addition of restoration of TMZ sensitivity, silencing of H19 leads to the reversal of epithelialmesenchymal transition (EMT) in GBM cell lines through upregulation of E-cadherin and downregulation of Vimentin and zinc finger E-box binding homeobox 1 (ZEB1) expression [160]. These findings provide rationale for future investigations on targeting the oncogenic role of H19 in GBM as a novel avenue to overcome GBM drug resistance.

The Hox transcript antisense intergenic RNA (HOTAIR) is another lncRNA whose expression is significantly upregulated in GBM cells and plays a critical role in cell cycle progression through mechanistic binding to the $5^{\prime}$ domain of the polycomb repressive complex 2 (PRC2) [161]. In terms of TMZ resistance in GBM, it appears that HOTAIR modulates abnormal expression of Hexokinase 2 (HK2), a regulator of glycolysis and chemo-resistance. It was recently demonstrated that depletion of HOTAIR in GBM cells could suppress HK2 expression in protein and mRNA levels by targeting miR-125, therefore inhibiting cell proliferation and further enhancing the cytotoxicity of TMZ both in vitro and in vivo [162]. The above observations support a functional and targetable role for HOTAIR in GBM glycolytic metabolism and chemo-resistance reprogramming.

SOX2 Overlapping Transcript (SOX2OT) is an oncogenic lncRNA implicated in GBM cell proliferation and TMZ resistance [163]. SRY-Box Transcription Factor 2 (SOX2) is a transcription factor regulated by SOX2OT, and both SOX2 and SOX2OT are significantly upregulated in TMZ-resistant GBM cells [163]. Mechanistically, SOX2OT modulates TMZ sensitivity through demethylation of the SOX2 promoter and subsequent upregulation of SOX2 expression as well as activation of the Wnt5a/b-catenin pathway [163]. The downstream impact of SOX2OT activation cascade entails apoptosis inhibition, tumor proliferation, and TMZ resistance. Efforts to exploits vulnerabilities in SOX2OT/SOX2/Wnt5a/b-catenin signaling cascade provides a novel avenue for targeting TMZ resistance in GBM.

FOXD2 Adjacent Opposite Strand RNA 1 (FoxD2-AS1) is an oncogenic lncRNA that is particularly interesting given its potential impact on MGMT methylation in GBM. As previously alluded, MGMT methylation status is a strong predictor of TMZ sensitivity in GBM whereby hypomethylation promotes TMZ resistance and hypermethylation enhances TMZ sensitivity. Recently, it was reported that FoxD2-AS1 expression was correlated with worse outcomes for GBM patients, and FoxD2-AS1 was responsible for GBM malignant transformation and TMZ resistance [164]. Furthermore, high FoxD2-AS1 expressions correlated with hypomethylation of the MGMT promoter in GBM patients [164]. Interestingly, genetic silencing of FoxD2-AS1 rendered the MGMT promoter hypermethylated and restored TMZ sensitivity in GBM [164]. These observations provide valuable insights on restoring TMZ sensitivity through regulation of MGMT promoter.

There is clearly mounting evidence from multiple studies that lncRNAs play an important role in GBM drug resistance through a variety of mechanisms (Figure 4). It is also apparent that lncRNAs activity can be modulated to successfully reverse GBM malignant phenotypes and restore sensitivity to TMZ. Further research is necessary for optimal and selective targeting of lncRNAs to overcome GBM resistance while simultaneously minimizing unwanted global effects.

\section{Conclusions}

GBM remains one of the most lethal cancers despite a significant scientific advance in our understanding of the molecular underpinnings of GBM tumorigenesis. There are 
significant challenges in developing impactful therapies to improve the outcomes of GBM patients. So far, TMZ plus RT remains the most effective therapy, yet the durability of response is often short-lived secondary to resistance evolution largely driven through epigenetic mechanisms. To generate impactful therapies that could improve outcomes for GBM patients, contextual understanding and targeting of treatment-induced epigenetic modifications is paramount. It will therefore be important that future studies focus on elucidating epigenetic targets of divergent evolution in GBM stem cells using appropriate models.

To date, epigenetic drugs have not significantly improved survival in GBM. Furthermore, the global effects of these drugs on epigenetic modifications have resulted in significant toxicities, thereby limiting tolerance to treatment. Therefore, future efforts should be directed towards rational epigenetic targeting to improve TMZ response while simultaneously minimizing systemic toxicity.

Author Contributions: A.B.E. designed the study; Q.W., A.E.B. and A.B.E. collected data, analyzed data, and wrote the manuscript. All authors have read and agreed to the published version of the manuscript.

Funding: The study was supported by the Moffitt Cancer Center Foundation (A.B.E.); and by National Institute of Health (NIH) Grant No. R21-NS120800 (A.B.E.).

Institutional Review Board Statement: Not applicable.

Data Availability Statement: Not applicable.

Acknowledgments: This work has been supported in part by the Biostatistics and Bioinformatics Shared Resource at the H. Lee Moffitt Cancer Center \& Research Institute, an NCI designated Comprehensive Cancer Center (P30-CA076292).

Conflicts of Interest: The authors declare no conflict of interest.

\section{Abbreviations}

$\begin{array}{ll}\text { BRG1 } & \text { brahma-related gene-1 } \\ \text { DNMT } & \text { DNA methyltransferase } \\ \text { EMT } & \text { epithelial-mesenchymal transition } \\ \text { EZH2 } & \text { enhancer of zeste homolog } \\ \text { FoxD2-AS1 } & \text { FOXD2 Adjacent Opposite Strand RNA 1 } \\ \text { GBM } & \text { glioblastoma } \\ \text { GSC } & \text { GBM stem cell } \\ \text { HAT } & \text { histone acetyltransferase } \\ \text { HDAC } & \text { histone deacetylase } \\ \text { HMT } & \text { histone methyltransferase } \\ \text { KDM } & \text { lysine-specific demethylase } \\ \text { lncRNA } & \text { long Non-Coding RNAs } \\ \text { MALAT1 } & \text { metastasis-associated lung adenocarcinoma transcript 1 } \\ \text { MGMT } & \text { O-6-methylguanine-DNA methyltransferase } \\ \text { NF- } \text { B } & \text { nuclear factor kappa-light-chain-enhancer of activated B cells } \\ \text { PARP1 } & \text { poly (ADP-ribose) polymerase 1 } \\ \text { PRC2 } & \text { polycomb repressive complex 2 } \\ \text { PRMTs } & \text { protein arginine methyltransferases } \\ \text { SOX2 } & \text { SRY-Box Transcription Factor 2 } \\ \text { SOX2OT } & \text { SOX2 Overlapping Transcript } \\ \text { STAT3 } & \text { signal transducer and activator of transcription 3 } \\ \text { SWI/SNF } & \text { suppressor SWItch/Sucrose Non-Fermentable } \\ \text { TMZ } & \text { temozolomide }\end{array}$

\section{References}

1. Stupp, R.; Mason, W.P.; van den Bent, M.J.; Weller, M.; Fisher, B.; Taphoorn, M.J.; Belanger, K.; Brandes, A.A.; Marosi, C.; Bogdahn, U.; et al. Radiotherapy plus concomitant and adjuvant temozolomide for glioblastoma. N. Engl. J. Med. 2005, 352, 987-996. [CrossRef] [PubMed] 
2. Wong, E.T.; Hess, K.R.; Gleason, M.J.; Jaeckle, K.A.; Kyritsis, A.P.; Prados, M.D.; Levin, V.A.; Yung, W.K. Outcomes and prognostic factors in recurrent glioma patients enrolled onto phase II clinical trials. J. Clin. Oncol. 1999, 17, 2572-2578. [CrossRef] [PubMed]

3. Yung, W.K.; Albright, R.E.; Olson, J.; Fredericks, R.; Fink, K.; Prados, M.D.; Brada, M.; Spence, A.; Hohl, R.J.; Shapiro, W.; et al. A phase II study of temozolomide vs. procarbazine in patients with glioblastoma multiforme at first relapse. Br. J. Cancer 2000, 83, 588-593. [CrossRef]

4. Boumahdi, S.; de Sauvage, F.J. The great escape: Tumour cell plasticity in resistance to targeted therapy. Nat. Rev. Drug Discov. 2020, 19, 39-56. [CrossRef] [PubMed]

5. Jonchère, B.; Vétillard, A.; Toutain, B.; Guette, C.; Coqueret, O. Contribution to tumor escape and chemotherapy response: A choice between senescence and apoptosis in heterogeneous tumors. Bull. Cancer 2016, 103, 73-86. [CrossRef]

6. Kemper, K.; de Goeje, P.L.; Peeper, D.S.; van Amerongen, R. Phenotype switching: Tumor cell plasticity as a resistance mechanism and target for therapy. Cancer Res. 2014, 74, 5937-5941. [CrossRef]

7. Duesberg, P.; Stindl, R.; Hehlmann, R. Explaining the high mutation rates of cancer cells to drug and multidrug resistance by chromosome reassortments that are catalyzed by aneuploidy. Proc. Natl. Acad. Sci. USA 2000, 97, 14295-14300. [CrossRef]

8. Duesberg, P.; Stindl, R.; Hehlmann, R. Origin of multidrug resistance in cells with and without multidrug resistance genes: Chromosome reassortments catalyzed by aneuploidy. Proc. Natl. Acad. Sci. USA 2001, 98, 11283-11288. [CrossRef]

9. Hata, A.N.; Niederst, M.J.; Archibald, H.L.; Gomez-Caraballo, M.; Siddiqui, F.M.; Mulvey, H.E.; Maruvka, Y.E.; Ji, F.; Bhang, H.E.; Krishnamurthy Radhakrishna, V.; et al. Tumor cells can follow distinct evolutionary paths to become resistant to epidermal growth factor receptor inhibition. Nat. Med. 2016, 22, 262-269. [CrossRef]

10. Mantovani, F.; Collavin, L.; del Sal, G. Mutant p53 as a guardian of the cancer cell. Cell Death Differ. 2019, 26, 199-212. [CrossRef] [PubMed]

11. Saleem, H.; Kulsoom Abdul, U.; Küçükosmanoglu, A.; Houweling, M.; Cornelissen, F.M.G.; Heiland, D.H.; Hegi, M.E.; Kouwenhoven, M.C.M.; Bailey, D.; Würdinger, T.; et al. The TICking clock of EGFR therapy resistance in glioblastoma: Target Independence or target Compensation. Drug Resist. Updat. 2019, 43, 29-37. [CrossRef] [PubMed]

12. Bell, C.C.; Fennell, K.A.; Chan, Y.C.; Rambow, F.; Yeung, M.M.; Vassiliadis, D.; Lara, L.; Yeh, P.; Martelotto, L.G.; Rogiers, A.; et al. Targeting enhancer switching overcomes non-genetic drug resistance in acute myeloid leukaemia. Nat. Commun. 2019, 10, 2723. [CrossRef] [PubMed]

13. Brown, R.; Curry, E.; Magnani, L.; Wilhelm-Benartzi, C.S.; Borley, J. Poised epigenetic states and acquired drug resistance in cancer. Nat. Rev. Cancer 2014, 14, 747-753. [CrossRef]

14. Hinohara, K.; Wu, H.J.; Vigneau, S.; McDonald, T.O.; Igarashi, K.J.; Yamamoto, K.N.; Madsen, T.; Fassl, A.; Egri, S.B.; Papanastasiou, M.; et al. KDM5 Histone Demethylase Activity Links Cellular Transcriptomic Heterogeneity to Therapeutic Resistance. Cancer Cell 2018, 34, 939-953.e9. [CrossRef] [PubMed]

15. Knoechel, B.; Roderick, J.E.; Williamson, K.E.; Zhu, J.; Lohr, J.G.; Cotton, M.J.; Gillespie, S.M.; Fernandez, D.; Ku, M.; Wang, H.; et al. An epigenetic mechanism of resistance to targeted therapy in T cell acute lymphoblastic leukemia. Nat. Genet. 2014, 46, 364-370. [CrossRef]

16. Liau, B.B.; Sievers, C.; Donohue, L.K.; Gillespie, S.M.; Flavahan, W.A.; Miller, T.E.; Venteicher, A.S.; Hebert, C.H.; Carey, C.D.; Rodig, S.J.; et al. Adaptive Chromatin Remodeling Drives Glioblastoma Stem Cell Plasticity and Drug Tolerance. Cell Stem. Cell 2017, 20, 233-246.e7. [CrossRef]

17. Shaffer, S.M.; Dunagin, M.C.; Torborg, S.R.; Torre, E.A.; Emert, B.; Krepler, C.; Beqiri, M.; Sproesser, K.; Brafford, P.A.; Xiao, M.; et al. Rare cell variability and drug-induced reprogramming as a mode of cancer drug resistance. Nature 2017, 546, 431-435. [CrossRef] [PubMed]

18. Sharma, S.V.; Lee, D.Y.; Li, B.; Quinlan, M.P.; Takahashi, F.; Maheswaran, S.; McDermott, U.; Azizian, N.; Zou, L.; Fischbach, M.A.; et al. A chromatin-mediated reversible drug-tolerant state in cancer cell subpopulations. Cell 2010, 141, 69-80. [CrossRef] [PubMed]

19. Zawistowski, J.S.; Bevill, S.M.; Goulet, D.R.; Stuhlmiller, T.J.; Beltran, A.S.; Olivares-Quintero, J.F.; Singh, D.; Sciaky, N.; Parker, J.S.; Rashid, N.U.; et al. Enhancer Remodeling during Adaptive Bypass to MEK Inhibition Is Attenuated by Pharmacologic Targeting of the P-TEFb Complex. Cancer Discov. 2017, 7, 302-321. [CrossRef] [PubMed]

20. Aldape, K.; Zadeh, G.; Mansouri, S.; Reifenberger, G.; von Deimling, A. Glioblastoma: Pathology, molecular mechanisms and markers. Acta Neuropathol. 2015, 129, 829-848. [CrossRef]

21. Chiang, J.H.; Cheng, W.S.; Hood, L.; Tian, Q. An epigenetic biomarker panel for glioblastoma multiforme personalized medicine through DNA methylation analysis of human embryonic stem cell-like signature. Omics 2014, 18, 310-323. [CrossRef]

22. Henriksen, M.; Johnsen, K.B.; Andersen, H.H.; Pilgaard, L.; Duroux, M. MicroRNA expression signatures determine prognosis and survival in glioblastoma multiforme-a systematic overview. Mol. Neurobiol. 2014, 50, 896-913. [CrossRef] [PubMed]

23. Pangeni, R.P.; Zhang, Z.; Alvarez, A.A.; Wan, X.; Sastry, N.; Lu, S.; Shi, T.; Huang, T.; Lei, C.X.; James, C.D.; et al. Genome-wide methylomic and transcriptomic analyses identify subtype-specific epigenetic signatures commonly dysregulated in glioma stem cells and glioblastoma. Epigenetics 2018, 13, 432-448. [CrossRef] [PubMed]

24. Zhou, L.; Tang, H.; Wang, F.; Chen, L.; Ou, S.; Wu, T.; Xu, J.; Guo, K. Bioinformatics analyses of significant genes, related pathways and candidate prognostic biomarkers in glioblastoma. Mol. Med. Rep. 2018, 18, 4185-4196. [CrossRef] [PubMed]

25. Dong, Z.; Cui, H. Epigenetic modulation of metabolism in glioblastoma. Semin. Cancer Biol. 2019, 57, 45-51. [CrossRef] [PubMed] 
26. Li, P.; Wu, M. Epigenetic Mechanisms of Glioblastoma. In Glioblastoma; de Vleeschouwer, S., Ed.; Codon Publications: Brisbane, Australia, 2017.

27. Uddin, M.S.; Mamun, A.A.; Alghamdi, B.S.; Tewari, D.; Jeandet, P.; Sarwar, M.S.; Ashraf, G.M. Epigenetics of glioblastoma multiforme: From molecular mechanisms to therapeutic approaches. In Seminars in Cancer Biology; Academic Press: Cambridge, MA, USA, 2020.

28. Allis, C.D.; Jenuwein, T. The molecular hallmarks of epigenetic control. Nat. Rev. Genet. 2016, 17, 487-500. [CrossRef]

29. Zhao, L.Y.; Song, J.; Liu, Y.; Song, C.X.; Yi, C. Mapping the epigenetic modifications of DNA and RNA. Protein Cell 2020, 11, 792-808. [CrossRef]

30. Dawson, M.A.; Kouzarides, T. Cancer epigenetics: From mechanism to therapy. Cell 2012, 150, 12-27. [CrossRef] [PubMed]

31. Lao, V.V.; Grady, W.M. Epigenetics and colorectal cancer. Nat. Rev. Gastroenterol. Hepatol. 2011, 8, 686-700. [CrossRef]

32. Nebbioso, A.; Tambaro, F.P.; Dell'Aversana, C.; Altucci, L. Cancer epigenetics: Moving forward. PLoS Genet. 2018, 14, e1007362. [CrossRef]

33. Wu, Y.; Sarkissyan, M.; Vadgama, J.V. Epigenetics in breast and prostate cancer. Methods Mol. Biol. 2015, 1238, 425-466.

34. $\mathrm{Hu}, \mathrm{Q} . ; \mathrm{Baeg}, \mathrm{G} . \mathrm{H}$. Role of epigenome in tumorigenesis and drug resistance. Food Chem. Toxicol. 2017, 109 Pt 1, 663-668. [CrossRef]

35. Bhargava, S.; Patil, V.; Mahalingam, K.; Somasundaram, K. Elucidation of the genetic and epigenetic landscape alterations in RNA binding proteins in glioblastoma. Oncotarget 2017, 8, 16650-16668. [CrossRef] [PubMed]

36. Ferreira, W.A.; Pinheiro Ddo, R.; Costa Junior, C.A.; Rodrigues-Antunes, S.; Araújo, M.D.; Leão Barros, M.B.; Teixeira, A.C.; Faro, T.A.; Burbano, R.R.; Oliveira, E.H.; et al. An update on the epigenetics of glioblastomas. Epigenomics 2016, 8, 1289-1305. [CrossRef]

37. Yan, K.; Yang, K.; Rich, J.N. The evolving landscape of glioblastoma stem cells. Curr. Opin. Neurol. 2013, 26, 701-707. [CrossRef] [PubMed]

38. Gusyatiner, O; Hegi, M.E. Glioma epigenetics: From subclassification to novel treatment options. Semin. Cancer Biol. 2018, 51, 50-58. [CrossRef] [PubMed]

39. Lee, D.H.; Ryu, H.W.; Won, H.R.; Kwon, S.H. Advances in epigenetic glioblastoma therapy. Oncotarget 2017, 8, 18577-18589. [CrossRef]

40. Feinberg, A.P. The Key Role of Epigenetics in Human Disease Prevention and Mitigation. N. Engl. J. Med. 2018, 378, 1323-1334. [CrossRef] [PubMed]

41. Biswas, S.; Rao, C.M. Epigenetic tools (The Writers, The Readers and The Erasers) and their implications in cancer therapy. Eur. J. Pharmacol. 2018, 837, 8-24. [CrossRef]

42. Klemm, S.L.; Shipony, Z.; Greenleaf, W.J. Chromatin accessibility and the regulatory epigenome. Nat. Rev. Genet. 2019, 20, 207-220. [CrossRef] [PubMed]

43. Alfarouk, K.O.; Stock, C.M.; Taylor, S.; Walsh, M.; Muddathir, A.K.; Verduzco, D.; Bashir, A.H.; Mohammed, O.Y.; Elhassan, G.O.; Harguindey, S.; et al. Resistance to cancer chemotherapy: Failure in drug response from ADME to P-gp. Cancer Cell Int. 2015, 15, 71. [CrossRef]

44. Housman, G.; Byler, S.; Heerboth, S.; Lapinska, K.; Longacre, M.; Snyder, N.; Sarkar, S. Drug resistance in cancer: An overview. Cancers 2014, 6, 1769-1792. [CrossRef]

45. Rueff, J.; Rodrigues, A.S. Cancer Drug Resistance: A Brief Overview from a Genetic Viewpoint. Methods Mol. Biol. 2016, 1395, 1-18.

46. Perrier, A.; Didelot, A.; Laurent-Puig, P.; Blons, H.; Garinet, S. Epigenetic Mechanisms of Resistance to Immune Checkpoint Inhibitors. Biomolecules 2020, 10, 1061. [CrossRef]

47. Ponnusamy, L.; Mahalingaiah, P.K.S.; Singh, K.P. Epigenetic reprogramming and potential application of epigenetic-modifying drugs in acquired chemotherapeutic resistance. Adv. Clin. Chem. 2020, 94, 219-259.

48. Shah, K.; Rawal, R.M. Genetic and Epigenetic Modulation of Drug Resistance in Cancer: Challenges and Opportunities. Curr. Drug Metab. 2019, 20, 1114-1131. [CrossRef]

49. Yang, C.; Zhang, J.; Ma, Y.; Wu, C.; Cui, W.; Wang, L. Histone methyltransferase and drug resistance in cancers. J. Exp. Clin. Cancer Res. 2020, 39, 173. [CrossRef] [PubMed]

50. Minata, M.; Audia, A.; Shi, J.; Lu, S.; Bernstock, J.; Pavlyukov, M.S.; Das, A.; Kim, S.H.; Shin, Y.J.; Lee, Y.; et al. Phenotypic Plasticity of Invasive Edge Glioma Stem-like Cells in Response to Ionizing Radiation. Cell Rep. 2019, 26, 1893-1905.e7. [CrossRef] [PubMed]

51. National Cancer Institute. Vorinostat and Temozolomide in Treating Patients with Malignant Gliomas. 2005. Available online: https: / ClinicalTrials.gov / show / NCT00268385 (accessed on 1 July 2021).

52. National Cancer Institute. Vorinostat, Temozolomide, and Radiation Therapy in Treating Patients with Newly Diagnosed Glioblastoma Multiforme. 2009. Available online: https:/ /ClinicalTrials.gov/show / NCT00731731 (accessed on 1 July 2021).

53. M.D. Anderson Cancer Center; Merck Sharp \& Dohme Corp. Vorinostat, Isotretinoin and Temozolomide in Adults with Recurrent Glioblastoma Multiforme (GBM). 2007. Available online: https://ClinicalTrials.gov/show/NCT00555399 (accessed on 1 July 2021).

54. Duke University; Genentech, Inc.; Merck Sharp \& Dohme Corp. Ph II SAHA and Bevacizumab for Recurrent Malignant Glioma Patients. 2013. Available online: https:/ / ClinicalTrials.gov/show/NCT01738646 (accessed on 1 July 2021).

55. National Cancer Institute; M.D. Anderson Cancer Center; Genentech, Inc.; Merck Sharp \& Dohme Corp.; Brain Tumor Trials Collaborative; Ohio State University Wexner Medical Center; Northwestern University Feinberg School of Medicine; UF Health 
Cancer Center at Orlando Health; Baylor Health Care System; MUSC Hollings Cancer Center; et al. Phase I/II Adaptive Randomized Trial of Bevacizumab versus Bevacizumab Plus Vorinostat in Adults with Recurrent Glioblastoma. 2011. Available online: https: / ClinicalTrials.gov/show / NCT01266031 (accessed on 1 July 2021).

56. H. Lee Moffitt Cancer Center and Research Institute; Merck Sharp \& Dohme Corp. A Phase I Trial of Vorinostat in Combination with Bevacizumab \& Irinotecan in Recurrent Glioblastoma. 2008. Available online: https:/ /ClinicalTrials.gov/show/NCT00762 255 (accessed on 1 July 2021).

57. Peters, K.; Genentech, Inc.; Merck Sharp \& Dohme Corp.; Duke University. Suberoylanilide Hydroxamic Acid (SAHA), Bevacizumab, Daily Temozolomide for Recurrent Malignant Gliomas. 2009. Available online: https://ClinicalTrials.gov/show / NCT00939991 (accessed on 1 July 2021).

58. National Cancer Institute. Vorinostat, Temozolomide, or Bevacizumab in Combination With Radiation Therapy Followed by Bevacizumab and Temozolomide in Young Patients with Newly Diagnosed High-Grade Glioma. 2010. Available online: https: / ClinicalTrials.gov / show / NCT01236560 (accessed on 1 July 2021).

59. National Cancer Institute. Vorinostat and Bortezomib in Treating Patients with Progressive, Recurrent Glioblastoma Multiforme. 2008. Available online: https:/ /ClinicalTrials.gov/show / NCT00641706 (accessed on 1 July 2021).

60. M.D. Anderson Cancer Center; Merck Sharp \& Dohme Corp. Phase I/II Vorinostat, Erlotinib and Temozolomide for Recurrent Glioblastoma Multiforme (GBM). 2011. Available online: https://ClinicalTrials.gov/show/NCT01110876 (accessed on 1 July 2021).

61. H. Lee Moffitt Cancer Center and Research Institute; Merck Sharp \& Dohme Corp. Pembrolizumab and Vorinostat Combined With Temozolomide for Newly Diagnosed Glioblastoma. 2018. Available online: https:/ /ClinicalTrials.gov/show / NCT03426891 (accessed on 1 July 2021).

62. Emory University; Johns Hopkins University; Spectrum Pharmaceuticals, Inc.; National Cancer Institute; National Institute of Neurological Disorders and Stroke. MRSI to Predict Response to RT/TMZ \pm Belinostat in GBM. 2014. Available online: https: / ClinicalTrials.gov / show / NCT02137759 (accessed on 1 July 2021).

63. National Cancer Institute; National Institute of Neurological Disorders and Stroke. Valproic Acid with Temozolomide and Radiation Therapy to Treat Brain Tumors. 2006. Available online: https://ClinicalTrials.gov/show/NCT00302159 (accessed on 1 July 2021).

64. Baylor College of Medicine. Valproic Acid and Radiation Followed by Maintenance Valproic Acid and Bevacizumab in Children with High Grade Gliomas or Diffuse Intrinsic Pontine Glioma. 2009. Available online: https:/ /ClinicalTrials.gov / show / NCT008 79437 (accessed on 1 July 2021).

65. University of Virginia. Stereotactic Radiosurgery with Nivolumab and Valproate in Patients with Recurrent Glioblastoma. 2016. Available online: https:/ /ClinicalTrials.gov/show /NCT02648633 (accessed on 1 July 2021).

66. Virginia Commonwealth University; National Cancer Institute. Sorafenib Tosylate, Valproic Acid, and Sildenafil Citrate in Treating Patients with Recurrent High-Grade Glioma. 2013. Available online: https:/ /ClinicalTrials.gov/show / NCT01817751 (accessed on 1 July 2021).

67. University of Göttingen; Deutsche Kinderkrebsstiftung; Hannover Medical School. International Cooperative Phase III Trial of the HIT-HGG Study Group (HIT-HGG-2013). 2018. Available online: https:/ / ClinicalTrials.gov/show/NCT03243461 (accessed on 1 July 2021).

68. Patrick, Y.; Wen, M.; Brigham and Women's Hospital; Massachusetts General Hospital; Beth Israel Deaconess Medical Center; Northwestern University; Universitu of Virginia; Genentech, Inc.; Novartis. LBH589 and Bevacizumab in Patients With Recurrent High Grade Glioma. 2009. Available online: https: / ClinicalTrials.gov/show / NCT00859222 (accessed on 1 July 2021).

69. Forma Therapeutics, Inc. A Study of FT 2102 in Participants with Advanced Solid Tumors and Gliomas with an IDH1 Mutation. 2018. Available online: https:/ /ClinicalTrials.gov/show / NCT03684811 (accessed on 1 July 2021).

70. Sanai, N.; Barrow Neurological Institute; Ivy Brain Tumor Center; BeiGene; St. Joseph's Hospital and Medical Center; Phoenix. Study of Pamiparib in Newly Diagnosed and rGBM. 2021. Available online: https: / ClinicalTrials.gov/show/NCT04614909 (accessed on 1 July 2021).

71. National Cancer Institute. Temozolomide with or without Veliparib in Treating Patients with Newly Diagnosed Glioblastoma Multiforme. 2014. Available online: https:/ /ClinicalTrials.gov/show/NCT02152982 (accessed on 1 July 2021).

72. Radiation Therapy Oncology Group; National Cancer Institute, and NRG Oncology. Veliparib and Temozolomide in Treating Patients with Recurrent Glioblastoma. 2010. Available online: https://ClinicalTrials.gov/show/NCT01026493 (accessed on 1 July 2021).

73. National Cancer Institute. Veliparib, Radiation Therapy, and Temozolomide in Treating Patients with Newly Diagnosed Malignant Glioma Without H3 K27M or BRAFV600 Mutations. 2018. Available online: https:/ /ClinicalTrials.gov/show / NCT03581292 (accessed on 1 July 2021).

74. Jones, P.A. Functions of DNA methylation: Islands, start sites, gene bodies and beyond. Nat. Rev. Genet. 2012, 13, 484-492. [CrossRef] [PubMed]

75. Lövkvist, C.; Dodd, I.B.; Sneppen, K.; Haerter, J.O. DNA methylation in human epigenomes depends on local topology of CpG sites. Nucleic Acids Res. 2016, 44, 5123-5132. [CrossRef]

76. Choudhury, S.R.; Cui, Y.; Milton, J.R.; Li, J.; Irudayaraj, J. Selective increase in subtelomeric DNA methylation: An epigenetic biomarker for malignant glioma. Clin. Epigenetics 2015, 7, 107. [CrossRef] 
77. Fernandez, A.F.; Bayón, G.F.; Sierra, M.I.; Urdinguio, R.G.; Toraño, E.G.; García, M.G.; Carella, A.; López, V.; Santamarina, P.; Pérez, R.F.; et al. Loss of $5 \mathrm{hmC}$ identifies a new type of aberrant DNA hypermethylation in glioma. Hum. Mol. Genet. 2018, 27, 3046-3059. [CrossRef] [PubMed]

78. Jia, D.; Lin, W.; Tang, H.; Cheng, Y.; Xu, K.; He, Y.; Geng, W.; Dai, Q. Integrative analysis of DNA methylation and gene expression to identify key epigenetic genes in glioblastoma. Aging 2019, 11, 5579-5592. [CrossRef] [PubMed]

79. Malta, T.M.; de Souza, C.F.; Sabedot, T.S.; Silva, T.C.; Mosella, M.S.; Kalkanis, S.N.; Snyder, J.; Castro, A.V.B.; Noushmehr, H. Glioma CpG island methylator phenotype (G-CIMP): Biological and clinical implications. Neuro-Oncology 2018, 20, 608-620. [CrossRef] [PubMed]

80. Wenger, A.; Vega, S.F.; Kling, T.; Bontell, T.O.; Jakola, A.S.; Carén, H. Intratumor DNA methylation heterogeneity in glioblastoma: Implications for DNA methylation-based classification. Neuro-Oncology 2019, 21, 616-627. [CrossRef]

81. Zhou, D.; Wan, Y.; Xie, D.; Wang, Y.; Wei, J.; Yan, Q.; Lu, P.; Mo, L.; Xie, J.; Yang, S.; et al. DNMT1 mediates chemosensitivity by reducing methylation of miRNA-20a promoter in glioma cells. Exp. Mol. Med. 2015, 47, e182. [CrossRef] [PubMed]

82. Esteller, M.; Garcia-Foncillas, J.; Andion, E.; Goodman, S.N.; Hidalgo, O.F.; Vanaclocha, V.; Baylin, S.B.; Herman, J.G. Inactivation of the DNA-repair gene MGMT and the clinical response of gliomas to alkylating agents. N. Engl. J. Med. 2000, 343, 1350-1354. [CrossRef] [PubMed]

83. Xipell, E.; Aragón, T.; Martínez-Velez, N.; Vera, B.; Idoate, M.A.; Martínez-Irujo, J.J.; Garzón, A.G.; Gonzalez-Huarriz, M.; Acanda, A.M.; Jones, C.; et al. Endoplasmic reticulum stress-inducing drugs sensitize glioma cells to temozolomide through downregulation of MGMT, MPG, and Rad51. Neuro-Oncology 2016, 18, 1109-1119. [CrossRef] [PubMed]

84. Hegi, M.E.; Diserens, A.C.; Gorlia, T.; Hamou, M.F.; de Tribolet, N.; Weller, M.; Kros, J.M.; Hainfellner, J.A.; Mason, W.; Mariani, L.; et al. MGMT gene silencing and benefit from temozolomide in glioblastoma. N. Engl. J. Med. 2005, 352, 997-1003. [CrossRef]

85. Quinn, J.A.; Desjardins, A.; Weingart, J.; Brem, H.; Dolan, M.E.; Delaney, S.M.; Vredenburgh, J.; Rich, J.; Friedman, A.H.; Reardon, D.A.; et al. Phase I trial of temozolomide plus O6-benzylguanine for patients with recurrent or progressive malignant glioma. J. Clin. Oncol. 2005, 23, 7178-7187. [CrossRef]

86. Quinn, J.A.; Jiang, S.X.; Reardon, D.A.; Desjardins, A.; Vredenburgh, J.J.; Rich, J.N.; Gururangan, S.; Friedman, A.H.; Bigner, D.D.; Sampson, J.H.; et al. Phase I trial of temozolomide plus O6-benzylguanine 5-day regimen with recurrent malignant glioma. Neuro-Oncology 2009, 11, 556-561. [CrossRef]

87. Wu, Q.; Berglund, A.E.; Wang, D.; MacAulay, R.J.; Mulé, J.J.; Etame, A.B. Paradoxical epigenetic regulation of XAF1 mediates plasticity towards adaptive resistance evolution in MGMT-methylated glioblastoma. Sci. Rep. 2019, 9, 14072. [CrossRef]

88. Barciszewska, A.M.; Gurda, D.; Głodowicz, P.; Nowak, S.; Naskręt-Barciszewska, M.Z. A New Epigenetic Mechanism of Temozolomide Action in Glioma Cells. PLoS ONE 2015, 10, e0136669. [CrossRef]

89. Choi, S.; Yu, Y.; Grimmer, M.R.; Wahl, M.; Chang, S.M.; Costello, J.F. Temozolomide-associated hypermutation in gliomas. Neuro-Oncology 2018, 20, 1300-1309. [CrossRef] [PubMed]

90. Wang, H.; Cai, S.; Ernstberger, A.; Bailey, B.J.; Wang, M.Z.; Cai, W.; Goebel, W.S.; Czader, M.B.; Crean, C.; Suvannasankha, A.; et al. Temozolomide-mediated DNA methylation in human myeloid precursor cells: Differential involvement of intrinsic and extrinsic apoptotic pathways. Clin. Cancer Res. 2013, 19, 2699-2709. [CrossRef] [PubMed]

91. Christoph, F.; Weikert, S.; Kempkensteffen, C.; Krause, H.; Schostak, M.; Miller, K.; Schrader, M. Regularly methylated novel pro-apoptotic genes associated with recurrence in transitional cell carcinoma of the bladder. Int. J. Cancer 2006, 119, 1396-1402 [CrossRef] [PubMed]

92. Esteller, M.; Hamilton, S.R.; Burger, P.C.; Baylin, S.B.; Herman, J.G. Inactivation of the DNA repair gene O6-methylguanine-DNA methyltransferase by promoter hypermethylation is a common event in primary human neoplasia. Cancer Res. 1999, 59, 793-797.

93. Soengas, M.S.; Capodieci, P.; Polsky, D.; Mora, J.; Esteller, M.; Opitz-Araya, X.; McCombie, R.; Herman, J.G.; Gerald, W.L.; Lazebnik, Y.A.; et al. Inactivation of the apoptosis effector Apaf-1 in malignant melanoma. Nature 2001, 409, 207-211. [CrossRef]

94. Chen, X.; Zhang, M.; Gan, H.; Wang, H.; Lee, J.H.; Fang, D.; Kitange, G.J.; He, L.; Hu, Z.; Parney, I.F.; et al. A novel enhancer regulates MGMT expression and promotes temozolomide resistance in glioblastoma. Nat. Commun. 2018, 9, 2949. [CrossRef] [PubMed]

95. Bai, Y.; Zhang, Q.G.; Wang, X.H. Downregulation of TES by hypermethylation in glioblastoma reduces cell apoptosis and predicts poor clinical outcome. Eur. J. Med. Res. 2014, 19, 66. [CrossRef]

96. Kratzsch, T.; Kuhn, S.A.; Joedicke, A.; Hanisch, U.K.; Vajkoczy, P.; Hoffmann, J.; Fichtner, I. Treatment with 5-azacitidine delay growth of glioblastoma xenografts: A potential new treatment approach for glioblastomas. J. Cancer Res. Clin. Oncol. 2018, 144, 809-819. [CrossRef] [PubMed]

97. Reichrath, S.; Müller, C.S.; Gleissner, B.; Pfreundschuh, M.; Vogt, T.; Reichrath, J. Notch- and vitamin D signaling in 1,25(OH)2D3resistant glioblastoma multiforme (GBM) cell lines. J. Steroid Biochem. Mol. Biol. 2010, 121, 420-424. [CrossRef]

98. Bannister, A.J.; Kouzarides, T. Regulation of chromatin by histone modifications. Cell Res. 2011, 21, 381-395. [CrossRef] [PubMed]

99. Kim, Y.Z. Altered histone modifications in gliomas. Brain Tumor. Res. Treat. 2014, 2, 7-21. [CrossRef]

100. Kreth, S.; Thon, N.; Kreth, F.W. Epigenetics in human gliomas. Cancer Lett. 2014, 342, 185-192. [CrossRef] [PubMed]

101. Nagarajan, R.P.; Costello, J.F. Epigenetic mechanisms in glioblastoma multiforme. Semin. Cancer Biol. 2009, 19, 188-197. [CrossRef]

102. Gan, L.; Yang, Y.; Li, Q.; Feng, Y.; Liu, T.; Guo, W. Epigenetic regulation of cancer progression by EZH2: From biological insights to therapeutic potential. Biomark. Res. 2018, 6, 10. [CrossRef] [PubMed] 
103. Zhang, Y.; Yu, X.; Chen, L.; Zhang, Z.; Feng, S. EZH2 overexpression is associated with poor prognosis in patients with glioma. Oncotarget 2017, 8, 565-573. [CrossRef]

104. Suvà, M.L.; Riggi, N.; Janiszewska, M.; Radovanovic, I.; Provero, P.; Stehle, J.C.; Baumer, K.; Le Bitoux, M.A.; Marino, D.; Cironi, L.; et al. EZH2 is essential for glioblastoma cancer stem cell maintenance. Cancer Res. 2009, 69, 9211-9218. [CrossRef]

105. Kim, E.; Kim, M.; Woo, D.H.; Shin, Y.; Shin, J.; Chang, N.; Oh, Y.T.; Kim, H.; Rheey, J.; Nakano, I.; et al. Phosphorylation of EZH2 activates STAT3 signaling via STAT3 methylation and promotes tumorigenicity of glioblastoma stem-like cells. Cancer Cell 2013, 23, 839-852. [CrossRef]

106. Bryant, J.P.; Heiss, J.; Banasavadi-Siddegowda, Y.K. Arginine Methylation in Brain Tumors: Tumor Biology and Therapeutic Strategies. Cells 2021, 10, 124. [CrossRef] [PubMed]

107. Raposo, A.E.; Piller, S.C. Protein arginine methylation: An emerging regulator of the cell cycle. Cell Div. 2018, 13, 3. [CrossRef]

108. Banasavadi-Siddegowda, Y.K.; Welker, A.M.; An, M.; Yang, X.; Zhou, W.; Shi, G.; Imitola, J.; Li, C.; Hsu, S.; Wang, J.; et al. PRMT5 as a druggable target for glioblastoma therapy. Neuro-Oncology 2018, 20, 753-763. [CrossRef] [PubMed]

109. Han, X.; Li, R.; Zhang, W.; Yang, X.; Wheeler, C.G.; Friedman, G.K.; Province, P.; Ding, Q.; You, Z.; Fathallah-Shaykh, H.M.; et al Expression of PRMT5 correlates with malignant grade in gliomas and plays a pivotal role in tumor growth in vitro. J. Neuro-Oncol. 2014, 118, 61-72. [CrossRef] [PubMed]

110. Holmes, B.; Benavides-Serrato, A.; Saunders, J.T.; Landon, K.A.; Schreck, A.J.; Nishimura, R.N.; Gera, J. The protein arginine methyltransferase PRMT5 confers therapeutic resistance to mTOR inhibition in glioblastoma. J. Neuro-Oncol. 2019, 145, 11-22. [CrossRef]

111. Wang, S.; Tan, X.; Yang, B.; Yin, B.; Yuan, J.; Qiang, B.; Peng, X. The role of protein arginine-methyltransferase 1 in gliomagenesis. BMB Rep. 2012, 45, 470-475. [CrossRef]

112. Banasavadi-Siddegowda, Y.K.; Russell, L.; Frair, E.; Karkhanis, V.A.; Relation, T.; Yoo, J.Y.; Zhang, J.; Sif, S.; Imitola, J.; Baiocchi, R.; et al. PRMT5-PTEN molecular pathway regulates senescence and self-renewal of primary glioblastoma neurosphere cells. Oncogene 2017, 36, 263-274. [CrossRef]

113. Sachamitr, P.; Ho, J.C.; Ciamponi, F.E.; Ba-Alawi, W.; Coutinho, F.J.; Guilhamon, P.; Kushida, M.M.; Cavalli, F.M.G.; Lee, L.; Rastegar, N.; et al. PRMT5 inhibition disrupts splicing and stemness in glioblastoma. Nat. Commun. 2021, 12, 979. [CrossRef]

114. Huang, T.; Yang, Y.; Song, X.; Wan, X.; Wu, B.; Sastry, N.; Horbinski, C.M.; Zeng, C.; Tiek, D.; Goenka, A.; et al. PRMT6 methylation of RCC1 regulates mitosis, tumorigenicity, and radiation response of glioblastoma stem cells. Mol. Cell 2021, 81, 1276-1291.e9. [CrossRef]

115. Kurt, I.C.; Sur, I.; Kaya, E.; Cingoz, A.; Kazancioglu, S.; Kahya, Z.; Toparlak, O.D.; Senbabaoglu, F.; Kaya, Z.; Ozyerli, E.; et al. KDM2B, an H3K36-specific demethylase, regulates apoptotic response of GBM cells to TRAIL. Cell Death Dis. 2017, 8, e2897. [CrossRef]

116. Wang, Y.; Zang, J.; Zhang, D.; Sun, Z.; Qiu, B.; Wang, X. KDM2B overexpression correlates with poor prognosis and regulates glioma cell growth. OncoTargets Ther. 2018, 11, 201-209. [CrossRef] [PubMed]

117. Staberg, M.; Rasmussen, R.D.; Michaelsen, S.R.; Pedersen, H.; Jensen, K.E.; Villingshøj, M.; Skjoth-Rasmussen, J.; Brennum, J.; Vitting-Seerup, K.; Poulsen, H.S.; et al. Targeting glioma stem-like cell survival and chemoresistance through inhibition of lysine-specific histone demethylase KDM2B. Mol. Oncol. 2018, 12, 406-420. [CrossRef]

118. Sareddy, G.R.; Nair, B.C.; Krishnan, S.K.; Gonugunta, V.K.; Zhang, Q.G.; Suzuki, T.; Miyata, N.; Brenner, A.J.; Brann, D.W.; Vadlamudi, R.K. KDM1 is a novel therapeutic target for the treatment of gliomas. Oncotarget 2013, 4, 18-28. [CrossRef]

119. Sareddy, G.R.; Viswanadhapalli, S.; Surapaneni, P.; Suzuki, T.; Brenner, A.; Vadlamudi, R.K. Novel KDM1A inhibitors induce differentiation and apoptosis of glioma stem cells via unfolded protein response pathway. Oncogene 2017, 36, 2423-2434. [CrossRef] [PubMed]

120. Banelli, B.; Daga, A.; Forlani, A.; Allemanni, G.; Marubbi, D.; Pistillo, M.P.; Profumo, A.; Romani, M. Small molecules targeting histone demethylase genes (KDMs) inhibit growth of temozolomide-resistant glioblastoma cells. Oncotarget 2017, 8, 34896-34910. [CrossRef] [PubMed]

121. Romani, M.; Daga, A.; Forlani, A.; Pistillo, M.P.; Banelli, B. Targeting of Histone Demethylases KDM5A and KDM6B Inhibits the Proliferation of Temozolomide-Resistant Glioblastoma Cells. Cancers 2019, 11, 878. [CrossRef]

122. Sui, A.; Xu, Y.; Li, Y.; Hu, Q.; Wang, Z.; Zhang, H.; Yang, J.; Guo, X.; Zhao, W. The pharmacological role of histone demethylase JMJD3 inhibitor GSK-J4 on glioma cells. Oncotarget 2017, 8, 68591-68598. [CrossRef] [PubMed]

123. Barneda-Zahonero, B.; Parra, M. Histone deacetylases and cancer. Mol. Oncol. 2012, 6, 579-589. [CrossRef] [PubMed]

124. Weichert, W. HDAC expression and clinical prognosis in human malignancies. Cancer Lett. 2009, 280, 168-176. [CrossRef]

125. Diss, E.; Nalabothula, N.; Nguyen, D.; Chang, E.; Kwok, Y.; Carrier, F. Vorinostat ${ }^{\text {SAHA }}$ Promotes Hyper-Radiosensitivity in Wild Type p53 Human Glioblastoma Cells. JSM Clin. Oncol. Res. 2014, 2, 1004. Available online: http:/ /www.jscimedcentral.com/ Oncology/oncology-2-1004.php (accessed on 1 July 2021).

126. Kim, J.H.; Shin, J.H.; Kim, I.H. Susceptibility and radiosensitization of human glioblastoma cells to trichostatin A, a histone deacetylase inhibitor. Int. J. Radiat. Oncol. Biol. Phys. 2004, 59, 1174-1180. [CrossRef]

127. Chen, J.C.; Lee, I.N.; Huang, C.; Wu, Y.P.; Chung, C.Y.; Lee, M.H.; Lin, M.H.; Yang, J.T. Valproic acid-induced amphiregulin secretion confers resistance to temozolomide treatment in human glioma cells. BMC Cancer 2019, 19, 756. [CrossRef] [PubMed] 
128. Li, Z.Y.; Li, Q.Z.; Chen, L.; Chen, B.D.; Wang, B.; Zhang, X.J.; Li, W.P. Histone Deacetylase Inhibitor RGFP109 Overcomes Temozolomide Resistance by Blocking NF-кB-Dependent Transcription in Glioblastoma Cell Lines. Neurochem. Res. 2016, 41, 3192-3205. [CrossRef] [PubMed]

129. Wang, Z.; Hu, P.; Tang, F.; Lian, H.; Chen, X.; Zhang, Y.; He, X.; Liu, W.; Xie, C. HDAC6 promotes cell proliferation and confers resistance to temozolomide in glioblastoma. Cancer Lett. 2016, 379, 134-142. [CrossRef]

130. Wu, Y.; Dong, L.; Bao, S.; Wang, M.; Yun, Y.; Zhu, R. FK228 augmented temozolomide sensitivity in human glioma cells by blocking PI3K/AKT/mTOR signal pathways. Biomed. Pharm. 2016, 84, 462-469. [CrossRef] [PubMed]

131. Zhang, Z.; Wang, Y.; Chen, J.; Tan, Q.; Xie, C.; Li, C.; Zhan, W.; Wang, M. Silencing of histone deacetylase 2 suppresses malignancy for proliferation, migration, and invasion of glioblastoma cells and enhances temozolomide sensitivity. Cancer Chemother. Pharmacol. 2016, 78, 1289-1296. [CrossRef]

132. McClure, J.J.; Li, X.; Chou, C.J. Advances and Challenges of HDAC Inhibitors in Cancer Therapeutics. Adv. Cancer Res. 2018, $138,183-211$.

133. Zhao, C.; Dong, H.; Xu, Q.; Zhang, Y. Histone deacetylase (HDAC) inhibitors in cancer: A patent review (2017-present). Expert Opin. Ther. Pat. 2020, 30, 263-274. [CrossRef]

134. Galanis, E.; Anderson, S.K.; Miller, C.R.; Sarkaria, J.N.; Jaeckle, K.; Buckner, J.C.; Ligon, K.L.; Ballman, K.V.; Moore, D.F., Jr.; Nebozhyn, M.; et al. Phase I/II trial of vorinostat combined with temozolomide and radiation therapy for newly diagnosed glioblastoma: Results of Alliance N0874/ABTC 02. Neuro-Oncology 2018, 20, 546-556. [CrossRef] [PubMed]

135. Friday, B.B.; Anderson, S.K.; Buckner, J.; Yu, C.; Giannini, C.; Geoffroy, F.; Schwerkoske, J.; Mazurczak, M.; Gross, H.; Pajon, E.; et al. Phase II trial of vorinostat in combination with bortezomib in recurrent glioblastoma: A north central cancer treatment group study. Neuro-Oncology 2012, 14, 215-221. [CrossRef]

136. Iwamoto, F.M.; Lamborn, K.R.; Kuhn, J.G.; Wen, P.Y.; Yung, W.K.A.; Gilbert, M.R.; Chang, S.M.; Lieberman, F.S.; Prados, M.D.; Fine, H.A. A phase I/II trial of the histone deacetylase inhibitor romidepsin for adults with recurrent malignant glioma: North American Brain Tumor Consortium Study 03-03. Neuro-Oncology 2011, 13, 509-516. [CrossRef]

137. Shi, W.; Palmer, J.D.; Werner-Wasik, M.; Andrews, D.W.; Evans, J.J.; Glass, J.; Kim, L.; Bar-Ad, V.; Judy, K.; Farrell, C.; et al. Phase I trial of panobinostat and fractionated stereotactic re-irradiation therapy for recurrent high grade gliomas. J. Neuro-Oncol. 2016, 127, 535-539. [CrossRef] [PubMed]

138. Singh, M.M.; Manton, C.A.; Bhat, K.P.; Tsai, W.W.; Aldape, K.; Barton, M.C.; Chandra, J. Inhibition of LSD1 sensitizes glioblastoma cells to histone deacetylase inhibitors. Neuro-Oncology 2011, 13, 894-903. [CrossRef] [PubMed]

139. Passeri, D.; Camaioni, E.; Liscio, P.; Sabbatini, P.; Ferri, M.; Carotti, A.; Giacchè, N.; Pellicciari, R.; Gioiello, A.; Macchiarulo, A Concepts and Molecular Aspects in the Polypharmacology of PARP-1 Inhibitors. ChemMedChem 2016, 11, 1219-1226. [CrossRef] [PubMed]

140. Ganguly, D.; Sims, M.; Cai, C.; Fan, M.; Pfeffer, L.M. Chromatin Remodeling Factor BRG1 Regulates Stemness and Chemosensitivity of Glioma Initiating Cells. Stem Cells 2018, 36, 1804-1815. [CrossRef]

141. Hiramatsu, H.; Kobayashi, K.; Kobayashi, K.; Haraguchi, T.; Ino, Y.; Todo, T.; Iba, H. The role of the SWI/SNF chromatin remodeling complex in maintaining the stemness of glioma initiating cells. Sci. Rep. 2017, 7, 889. [CrossRef]

142. Bruns, A.-F.; Rippaus, N.; Droop, A.; Al-Jabri, M.; Care, M.; Jenkinson, M.; Brodbelt, A.; Chakrabarty, A.; Ismail, A.; Short, S.; et al. Chromatin remodelling to facilitate treatment resistance in glioblastoma. Neuro-Oncology 2019, 21 (Suppl. S4), iv7. [CrossRef]

143. National Cancer Institute. Olaparib in Treating Patients with Advanced Glioma, Cholangiocarcinoma, or Solid Tumors with IDH1 or IDH2 Mutations. 2018. Available online: https: / ClinicalTrials.gov/show / NCT03212274 (accessed on 1 July 2021).

144. Kung, J.T.; Colognori, D.; Lee, J.T. Long noncoding RNAs: Past, present, and future. Genetics 2013, 193, 651-669. [CrossRef] [PubMed]

145. Fang, Y.; Fullwood, M.J. Roles, Functions, and Mechanisms of Long Non-coding RNAs in Cancer. Genom. Proteom. Bioinform. 2016, 14, 42-54. [CrossRef]

146. Wang, P.; Ren, Z.; Sun, P. Overexpression of the long non-coding RNA MEG3 impairs in vitro glioma cell proliferation. J. Cell Biochem. 2012, 113, 1868-1874. [CrossRef]

147. Yao, Y.; Ma, J.; Xue, Y.; Wang, P.; Li, Z.; Liu, J.; Chen, L.; Xi, Z.; Theng, H.; Wang, Z.; et al. Knockdown of long non-coding RNA XIST exerts tumor-suppressive functions in human glioblastoma stem cells by up-regulating miR-152. Cancer Lett. 2015, 359, 75-86. [CrossRef]

148. Gutschner, T.; Diederichs, S. The hallmarks of cancer: A long non-coding RNA point of view. RNA Biol. 2012, 9, 703-719. [CrossRef]

149. Zhao, C.; Gao, Y.; Guo, R.; Li, H.; Yang, B. Microarray expression profiles and bioinformatics analysis of mRNAs, lncRNAs, and circRNAs in the secondary temozolomide-resistant glioblastoma. Investig. New Drugs 2020, 38, 1227-1235. [CrossRef] [PubMed]

150. Cai, T.; Liu, Y.; Xiao, J. Long noncoding RNA MALAT1 knockdown reverses chemoresistance to temozolomide via promoting microRNA-101 in glioblastoma. Cancer Med. 2018, 7, 1404-1415. [CrossRef]

151. Kim, S.S.; Harford, J.B.; Moghe, M.; Rait, A.; Pirollo, K.F.; Chang, E.H. Targeted nanocomplex carrying siRNA against MALAT1 sensitizes glioblastoma to temozolomide. Nucleic Acids Res. 2018, 46, 1424-1440. [CrossRef] [PubMed]

152. Vassallo, I.; Zinn, P.; Lai, M.; Rajakannu, P.; Hamou, M.F.; Hegi, M.E. WIF1 re-expression in glioblastoma inhibits migration through attenuation of non-canonical WNT signaling by downregulating the lncRNA MALAT1. Oncogene 2016, $35,12-21$. [CrossRef] 
153. Voce, D.J.; Bernal, G.M.; Wu, L.; Crawley, C.D.; Zhang, W.; Mansour, N.M.; Cahill, K.E.; Szymura, S.J.; Uppal, A.; Raleigh, D.R.; et al. Temozolomide Treatment Induces lncRNA MALAT1 in an NF- $k B$ and p53 Codependent Manner in Glioblastoma. Cancer Res. 2019, 79, 2536-2548. [CrossRef] [PubMed]

154. Xiong, Z.; Wang, L.; Wang, Q.; Yuan, Y. LncRNA MALAT1/miR-129 axis promotes glioma tumorigenesis by targeting SOX2. J. Cell Mol. Med. 2018, 22, 3929-3940. [CrossRef] [PubMed]

155. Chen, W.; Xu, X.K.; Li, J.L.; Kong, K.K.; Li, H.; Chen, C.; He, J.; Wang, F.; Li, P.; Ge, X.S.; et al. MALAT1 is a prognostic factor in glioblastoma multiforme and induces chemoresistance to temozolomide through suppressing miR-203 and promoting thymidylate synthase expression. Oncotarget 2017, 8, 22783-22799. [CrossRef]

156. Li, H.; Yuan, X.; Yan, D.; Li, D.; Guan, F.; Dong, Y.; Wang, H.; Liu, X.; Yang, B. Long Non-Coding RNA MALAT1 Decreases the Sensitivity of Resistant Glioblastoma Cell Lines to Temozolomide. Cell Physiol. Biochem. 2017, 42, 1192-1201. [CrossRef]

157. Ghafouri-Fard, S.; Esmaeili, M.; Taheri, M. H19 lncRNA: Roles in tumorigenesis. Biomed. Pharm. 2020, 123, 109774. [CrossRef] [PubMed]

158. Jiang, P.; Wang, P.; Sun, X.; Yuan, Z.; Zhan, R.; Ma, X.; Li, W. Knockdown of long noncoding RNA H19 sensitizes human glioma cells to temozolomide therapy. OncoTargets Ther. 2016, 9, 3501-3509.

159. Duan, S.; Li, M.; Wang, Z.; Wang, L.; Liu, Y. H19 induced by oxidative stress confers temozolomide resistance in human glioma cells via activating NF-кB signaling. OncoTargets Ther. 2018, 11, 6395-6404. [CrossRef] [PubMed]

160. Jia, L.; Tian, Y.; Chen, Y.; Zhang, G. The silencing of LncRNA-H19 decreases chemoresistance of human glioma cells to temozolomide by suppressing epithelial-mesenchymal transition via the Wnt/ $\beta$-Catenin pathway. OncoTargets Ther. 2018, 11, 313-321. [CrossRef] [PubMed]

161. Zhang, K.; Sun, X.; Zhou, X.; Han, L.; Chen, L.; Shi, Z.; Zhang, A.; Ye, M.; Wang, Q.; Liu, C.; et al. Long non-coding RNA HOTAIR promotes glioblastoma cell cycle progression in an EZH2 dependent manner. Oncotarget 2015, 6, 537-546. [CrossRef]

162. Zhang, J.; Chen, G.; Gao, Y.; Liang, H. HOTAIR/miR-125 axis-mediated Hexokinase 2 expression promotes chemoresistance in human glioblastoma. J. Cell Mol. Med. 2020, 24, 5707-5717. [CrossRef] [PubMed]

163. Liu, B.; Zhou, J.; Wang, C.; Chi, Y.; Wei, Q.; Fu, Z.; Lian, C.; Huang, Q.; Liao, C.; Yang, Z.; et al. LncRNA SOX2OT promotes temozolomide resistance by elevating SOX2 expression via ALKBH5-mediated epigenetic regulation in glioblastoma. Cell Death Dis. 2020, 11, 384. [CrossRef] [PubMed]

164. Shangguan, W.; Lv, X.; Tian, N. FoxD2-AS1 is a prognostic factor in glioma and promotes temozolomide resistance in a O(6)methylguanine-DNA methyltransferase-dependent manner. Korean J. Physiol. Pharmacol. 2019, 23, 475-482. [CrossRef] [PubMed] 